\title{
STEM Education Implementation at Early Age and Stakeholders' Opinions: The Case of Turkey
}

\author{
Remziye Ceylan and Beyza Akçay Malçok \\ Faculty of Education Yıldız Technical University
}

\section{Abstract}

This study aims to observe and examine the implementation of STEM education in early childhood and get opinions of teachers, parents and school administrators. The method of the study is the case study, one of the qualitative research methods. The data were collected with The Classroom Observation Protocol (COP) and SemiStructured Interviews with parents, teachers and vice-principals. The study was conducted in Turkey in a preschool education institution at a state university in Istanbul. This study was carried out with 15 children, two teachers, two vice-principals and five parents. In the study, the data were described using the method of content analysis. During the STEM training, 39 out of 48 indicators were observed by using the Classroom Observation Protocol (COP). It was concluded that the STEM education applied contains the desired STEM education items, and STEM education might be appropriately incorporated in early childhood classrooms. As the results of the interviews, it was concluded that parents did not have information about STEM education because they were not provided with enough information about it. Besides, teachers and vice-principals were satisfied with this training and they observed positive changes in children as the result of the STEM education.

Keywords: early age; engineering; mathematics; science; STEM; technology

\section{Introduction}

STEM is an approach involving the disciplines of science, technology, engineering and mathematics (Breiner et al., 2012). In the early 1990s, the National Science Foundation (NSF) used the abbreviation SMET for the disciplines "science, mathematics, engineering and technology" (Breiner et al., 2012; Sanders, 2009). However, this abbreviation, 
similar to other terms, changed over time and started to be used as STEM in 2001. The essential part of STEM education is to produce solutions for engineering problems of individuals by using science and mathematics knowledge, and by receiving support from technology (Kennedy \& Odell, 2014). One of the aims of STEM education is to contribute to the economic development of countries and to generate a labor force assisting in development (Kelley \& Knowles, 2016; Sanders, 2009).

STEM components enable new discoveries, especially in industry (White, 2014). Professions including STEM components making these inventions possible are identified, and the need for these professions is increasing (Aydagul \& Terzioglu, 2014). In addition, an agreement was reached that STEM education educates better teachers and students, and creates different job opportunities for countries (Breiner et al., 2012). Generating qualified workforce requires forming educational programs integrated with $21^{\text {st }}$ century skills. Therefore, it is of great importance to bring a new perspective to these programs by examining the existing education programs. The new perspective can be made possible by incorporating STEM disciplines and STEM education into current education programs since STEM is an approach that aims to find solutions to problems by using scientific methods and giving importance to individual and collaborative studies. In this approach, science, technology, engineering and mathematics have an important role in the development of many $21^{\text {st }}$ century skills such as problem solving, creativity, cooperation, analytical thinking and communication skills. Thus, the inclusion of STEM education into current educational programs will contribute to equipping individuals with $21^{\text {st }}$ century skills required by countries with an interdisciplinary view of STEM education (Erdogan et al., 2017). Educating individuals on the $21^{\text {st }}$ century skills is highly associated with the importance given to new educational programs at all levels of education, starting from an early age.

Children wonder, observe, search, predict and seek solutions like scientists from an early age. It is essential to support children's science curiosity at an early age in order for children to move towards research in the future (Aydagul \& Terzioglu, 2014; GencKumtepe et al., 2017). Thus, curiosity in early childhood will keep children interested in science and mathematics and will enable them to become successful scientists in the future (Soylu, 2016). In the studies conducted, it was found that STEM education implemented at an early age positively affects children's development (Aldemir \& Kermani, 2017; Balat \& Gunsen, 2017; Milford \& Tippet, 2015; Moomaw, 2013). In their study, Tippett and Milford (2017) emphasized that children are highly interested in STEM education implemented at early age, and they are more willing to learn outside the classroom as the result of this kind of education. Besides, Aldemir and Kermani (2017) emphasized in their study that STEM education implemented at an early age and included in the program will positively affect children's $21^{\text {st }}$ century skills such as problem solving, creative thinking and analysis. 


\section{STEM education and stakeholder's opinions}

STEM is becoming increasingly important at all levels of education. For the development of countries, STEM-based occupations and training of individuals with necessary skills for those professions have become inevitable in this day and age. In this respect, STEM education should be included in educational programs from early childhood education to higher education level (Aydagul \& Terzioglu, 2014; Breiner et al., 2012; Bybee, 2010). Although STEM education practices are of great importance at primary, secondary and higher education levels (Bolatli \& Korucu, 2018; Cotabish et al., 2013; Deveci, 2018; Gokbayrak \& Karisan, 2017; Ince, Misir, Kupeli, \& Firat, 2018; Park \& Yoo, 2013; Ross \& Gray, 2012; Robinson, 2016; Yildirim \& Turk, 2018), the implementation of STEM education in early childhood is a matter of interest. Lots of questions have been raised, especially about the implementation of this kind of education in Turkey, so studies have been carried out (Akgunduz \& Akpinar, 2018; Balat \& Gunsen, 2017; Basaran, 2018; Cetinkaya-Aydin et al., 2017).

In some studies it was emphasized that preschool education program in Turkey includes STEM education components (Akgunduz et al., 2015; Ata Akturk et al., 2018). In the program STEM disciplines are evaluated separately, although STEM education needs to be integrated into the program with an interdisciplinary approach (Ata Akturk et al., 2017; Aydagul \& Terzioglu, 2014; Soylu, 2016). Basaran (2018) also conducted a study on the suitability of the current educational program and physical conditions for STEM education practices. In Basaran's study, it was concluded that there was a lack of in-class physical materials to implement STEM education in preschool education institutions, that teachers had positive attitudes about STEM education and that, for children STEM education was implemented with, it had a positive effect on product demonstration, group work and cognitive engineering skills. In the same study, it was emphasized that STEM education is suitable and can be implemented effectively at an early age.

It is also an important issue to observe and examine whether the activities implemented in STEM education have STEM components. The Classroom Observation Protocol (COP) was developed by Milford and Tippet (2015). In addition, Cetinkaya-Aydin et al. (2017) translated this protocol into Turkish. Thus, they supported studies which observe and explain STEM education in Turkey, too. It was concluded that STEM education conducted with this protocol is valuable in studies focusing on early childhood (Cetinkaya-Aydin et al., 2017; Tippett \& Milford, 2017).

Besides observing the implementation of STEM education and evaluating it with the protocol, views of the stakeholders (parents, teachers and children) are of great importance. The stakeholders' opinions were included in the studies in which STEM education was investigated (Cetinkaya-Aydin et al., 2017; Tippett \& Milford, 2017; Akgunduz \& Akpinar, 2018; Basaran, 2018). In their study, Tippett and Milford (2017) showed that parents had positive attitudes towards STEM education and that they observed positive changes in their children. Also, teachers showed positive attitudes towards STEM education, so it was found that this kind of education is of great 
importance in early childhood. In addition, it was concluded that STEM education is necessary and should be implemented; however, it will put some responsibilities on teachers and contribute positively to students' development (Akgunduz et al., 2015; Basaran, 2018; Ugras, 2017; Ugras, \& Genc, 2018). Akgunduz and Akpinar (2018) found, as a result of their interviews, that STEM education increased the children's curiosity and motivation, and that children developed skills such as critical thinking, cooperation and communication. Moomaw and Davis (2010) concluded that STEM education at an early age helps children focus and support group work. Besides, Basaran (2018) found out the school administrators' views that STEM education increased the prestige of the school and provided benefits to teachers and students. Thus, it is emphasized in these studies, based both on the observation protocol and stakeholders' views, that STEM education can be appropriately incorporated in early childhood education (Akgunduz \& Akpinar, 2018; Basaran, 2018; Tippett \& Milford, 2017), but some shortcomings were observed (Akgunduz \& Akpinar, 2018; Basaran, 2018). Therefore, attention should be paid to studies focusing on STEM education in order to obtain detailed examination of the shortcomings observed in previous studies and opinions from more stakeholders on this issue. However, there is not enough research in this field in Turkey. The studies conducted so far emphasize the characteristics of STEM education (Arikan, 2018; Aydeniz, 2017; zamijeniti s Bahar et al., 2018; Yasar et al., 2018), teachers/prospective teachers' opinions on STEM education (Bakirci \& Kutlu, 2018; Gulgun et al., 2017; Ozbilen, 2018; Ugras \& Genc, 2018 ) or necessity and effects of STEM education on students at primary and high school levels (Bolatli \& Korucu, 2018; Cotabish et al., 2013; Deveci, 2018; Gokbayrak \& Karisan, 2017; Ince et al., 2018; Park \& Yoo, 2013; Ross \& Gray, 2012; Robinson, 2016; Yildirim \& Turk, 2018). Studies on STEM education in early childhood are limited (Akgunduz \& Akpinar, 2018; Balat \& Gunsen, 2017; Basaran, 2018; Milford \& Tippet, 2015; Tippett \& Milford, 2017; Yasar Ekici et al., 2018).

In this study, the following questions were investigated: "Can STEM education be appropriately incorporated in early childhood education?" and "What are teachers, parents and school administrators' opinions on the current STEM education?". Therefore, the aim of this study is to observe and examine the implementation of STEM education in early childhood education and to consider the implementation by taking into account the opinions of various stakeholders such as teachers, parents and school administrators.

\section{Methods}

Case study, one of the qualitative research methods, was selected as the method of the study. Case studies are carried out to observe details of one or more situations, events, contexts or social groups examined and to provide explanations for them (Buyukozturk et al., 2014; Johnson \& Christensen, 2014). In this study, the researcher 
aimed to understand the participants' opinions by asking general or in-depth questions during the interviews. In addition, it is important to establish a positive and confidential relationship with participants during the interviews, to enable them to express their opinions explicitly and give in-depth information to the researchers (Lester, 1999). In this study, in order to observe and examine the implementation of STEM education, class observations and semi-structured interviews with teachers, parents and school administrators were conducted.

The study was conducted in a preschool education institution accommodating 3-6 years old children at a state university in Istanbul. The school was opened two years ago and the number of children in the classes varies between 9 and 15. There are 97 children in a two-storey school building with a large garden. The school principal, two vice-principals, one counsellor, nine teachers and five members of the cleaning staff work at this school. The teachers' ages vary between 22 and 40, and their professional experience varies between 4 and 20 years. All of the teachers graduated from vocational high school for girls. With regard to the higher education, two teachers graduated from preschool education department in Open Education Faculty, and five have associate's degrees in child development and one in social services.

\section{Study Group}

This study was carried out with children, teachers, vice-principals and parents. 15 children in a kindergarten and the form teacher, a preschool teacher implementing STEM activities, 2 vice-principals in the school and 5 parents were included in the study. Children's ages varied between 5 and 6 years. Besides, these children experienced with STEM practices for the first time. The form teacher is a graduate of preschool education. This teacher has worked in the same school for 6 years. The teacher who implemented STEM activities has a preschool education degree and is attending MA studies. In addition, this teacher has completed academic studies in STEM education.

Two vice-principals in those two schools participated in the study and they graduated from the Child Development Department of the vocational high school for girls. One of them has 4 and the other has 16 years of professional experience, and both of them have worked as administrators for one year in their respective schools. Also, three mothers and two fathers were interviewed. Five parents who participated in the study were in different professional groups such as administrative, academic and support staff.

\section{Data Collection Tools}

In this study, The Classroom Observation Protocol (COP) developed by Milford and Tippet (2015) was used to collect information about STEM education and examine this education in Turkey. Besides, semi-structured interview forms developed by the researcher were used to examine the participants' views on STEM education. To determine the interview questions, the literature was reviewed by the researchers, and 
the researchers obtained opinions from three experts in the field - two in preschool education field and one in STEM education field. In the study, a total of four interview forms - The Semi-Structured Parental Interview Form, The Semi-Structured Teacher Interview Form A and Form B, and The Semi-Structured Vice-Principal Interview Form were used.

\section{Classroom Observation Protocol (COP)}

The Classroom Observation Protocol (COP) was developed by Milford and Tippet (2015). The purpose of this observation protocol is to understand the components of STEM education in early childhood and to help teachers include STEM education in their own educational processes. In addition, this protocol examines components of STEM education and effectiveness of it in the classroom context. This protocol consists of 4 dimensions, 16 sub-dimensions and 48 indicators. In addition, there are three indicators for each sub-dimension in this protocol.

Dimensions and sub-dimensions are listed as follows. The first dimension: Questioning (sub-dimensions: characteristics and nature, patterns and interactions); the second dimension: Play (pretend, socio-dramatic, constructive and exploring surroundings); the third dimension: Process Skills (sub-dimensions: observing, describing, categorizing, predicting and communicating), and the fourth dimension: NGSS Scientific and Engineering Practices (sub-dimensions: questions and problems, analysing and interpreting, math and computational thinking, explanations and designing solutions and argument).

This protocol shows how many of the indicators are observed during STEM education and how effectively it is implemented. During the evaluation process of the protocol, not the frequency of the indicators but the observance of behaviours in the indicators was taken into consideration (Milford \& Tippet, 2015). Thus, as the number of indicators observed during STEM education increases, it might be concluded that STEM education implemented in the classroom contains the expected STEM education components.

The Classroom Observation Protocol (COP) was translated into Turkish by Cetinkaya et al. (2017). The translated protocol, together with the original version, was submitted for the opinion of an expert whose native language is English and who has lived in Turkey for 20 years. Besides, the dimensions and indicators of the protocol translated into Turkish were evaluated by three field experts in terms of their relevance to the early childhood education. After the experts' feedback, the necessary data were collected and analyzed by three researchers, and Cohen's kappa coefficient was calculated (Cetinkaya-Aydin et al., 2017).

\section{Semi-Structured Parental Interview Form}

The Semi-Structured Parental Interview Form was developed by the researchers. This form aims to learn the thoughts of parents about STEM education implemented in 
the classes. The interview includes questions about the definition of STEM education, parents' opinions about STEM practices and the changes in children that parents observed after STEM practices.

\section{Semi-Structured Teacher Interview Form (A Form)}

The Semi-Structured Teacher Interview Form (A) was developed by the researchers to learn the teachers' ideas on STEM education after each STEM practice. Thus, after every practice, the teacher was asked questions about the points that were implemented well and those that should be developed.

\section{Semi-Structured Teacher Interview Form (B Form)}

The Semi-Structured Teacher Interview Form (B) was developed by the researchers to learn the teachers' opinions about STEM practices and the changes teachers observed in children. During the interview, teachers were asked about the definition of STEM education, STEM education implemented in preschool period, and changes observed in children after STEM education.

\section{Semi-Structured Vice-Principal Interview Form}

The Semi-Structured Vice-Principal Interview Form, developed by the researchers, aims to learn the opinions about current STEM education. The interview form includes questions about the definition of STEM education, STEM education implemented at school, changes observed in children and teachers after STEM practices.

\section{Implementation}

The study was conducted twice a week for eight weeks in the fall semester of the 2017-2018 academic year. Each practice took approximately 45 minutes. The practices were held in the classroom in the mornings. During the activities, the researcher was in the classroom. The researcher used a voice recorder in the class. After the practices, the researchers listened to those sound recordings and filled The Classroom Observation Protocol (COP). The class observation protocol was filled out by different researchers for the same activity. Then the researchers met and compared the indicators they determined, and so reached $100 \%$ consensus.

In this study, the interview method was used to understand the opinions of parents, teachers and vice-principals. At the end of the eighth week, after STEM education practices had been completed, the parents were contacted via telephone to inform them about the purpose of the study and it was stated that the participation was voluntary. Appointments were made with the voluntary parents. A total of five parents were interviewed. All interviews were carried out face-to-face in a comfortable and quiet environment in the parents' offices. Those interviews lasted approximately 30 minutes. During the interviews, a voice recorder was used with the permission of the participants. Those interviews were conducted to collect information about parents' 
opinions on STEM education and the changes they observed in their children after the education.

At the end of each activity, interviews were conducted with the teachers who implemented STEM practices to find out their opinions on those practices. Those interviews were held immediately after the practices and lasted for about 10 minutes. The interviews were conducted in a comfortable and quiet environment in the meeting room in the kindergarten where the implementation took place. Thus, the teachers' opinions about the implementation of each practice were included in the study. At the end of 8 weeks, after STEM education implementation had been completed, interviews were conducted with the teacher who implemented STEM education and with the class teacher. The interviews were again held in the meeting room in the kindergarten. During the interviews, a voice recorder was used with the participants' permission. Those interviews were conducted to get information about the teachers' ideas about STEM education and the changes they observed in children after the education.

Finally, after STEM education implementations were completed, interviews were held with the vice-principals. The interviews were conducted face to face, with appointment and in the vice-principals' comfortable and quiet offices. The interviews lasted around 30 minutes, and the interviews were based on the vice-principals' thoughts on STEM education. Besides, the vice-principals were asked questions about the changes they observed in both the teachers and the children, and the answers were recorded on the voice recorder with the participants' permission.

\section{Data analysis}

The data collected during the study were analyzed separately. The Classroom Observation Protocol (COP) was completed and evaluated as a result of observations in the classroom. The data collected from semi-structured interviews with the viceprincipals, parents and form teachers were described by using the content analysis method, which is one of the qualitative data analysis methods. Content analysis can be defined as a way to find out necessary concepts and relations that explain the data collected by examining the data in detail (Yildirim \& Şimşek, 1999). The interviews were transcribed first and then evaluated by the researchers. In the evaluations, the interview form and questions on those forms were evaluated separately. As a result of those evaluations, the researchers met and compared their themes. In this respect, themes were determined by reaching $100 \%$ consensus. Also, each participant was given codes according to their work in the institution, children's and parents' gender and the number of parents. For example, VP code refers to the vice-principal, CT to the class teacher, IT to the teacher implementing STEM practices, and MD1 to the first mother with a daughter. FS1 refers to the first father with a son. The numbers at the end of the codes were separated based on male and female parents. In this research, the data were collected to observe and examine the implementation of STEM education applied in early childhood education, as well as stakeholders' opinions (teachers, parents and 
school administrators') on STEM education. In addition, qualitative data analysis methods were used to analyse data.

\section{Results}

\section{Classroom Observation Protocol (COP)}

The Classroom Observation Protocol (COP) emphasizes whether there is an expected behaviour in STEM practices (Tippett \& Milford, 2017). In this context, not the frequency of the indicators but the observation of the behaviours in the indicators was evaluated in this study. Thus, as the number of indicators observed during STEM education increases, it might be concluded that STEM education in the classroom is more meaningful in the learning provided. Thus, it is also one of the objectives of the COP to help teachers to prepare STEM education lesson plans and to make the educational process in the implementation of these plans meaningful (Milford \& Tippet, 2015). Thus, the implementers of STEM education can observe both the STEM education and learning process within the classroom through this observation protocol. In this study, 39 out of 48 indicators were observed. In addition, the expected characteristics were met for each dimension and sub-dimension in the observation protocol (COP) applied. However, the number of indicators met in the sub-dimensions of the protocol varies. The indicators met in the protocol are shown in Table 1. Thus, due to a high number of indicators, it was concluded that STEM education throughout the study included the expected STEM education components. Furthermore, as a result of those data, it can be emphasized that STEM education is valuable in early childhood. It was concluded that STEM education was an appropriate education for early childhood, and it was appropriately incorporated in early age classrooms because of the fact that The Classroom Observation Protocol (COP) components were met throughout the study.

Table 1

Indicators Observed in The Classroom Observation Protocol

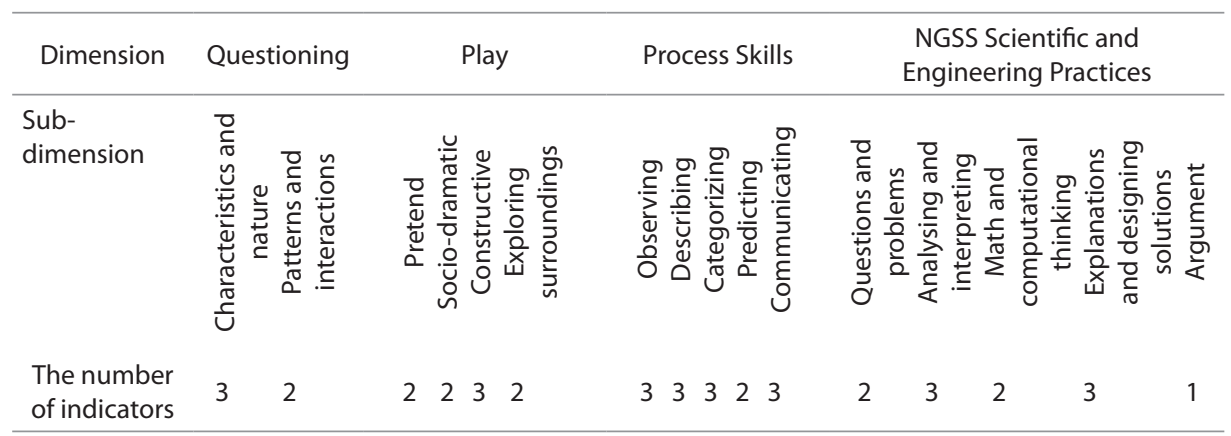

\section{Interviews with parents}

Parents were asked four different questions in terms of STEM education implemented in the classrooms of their children. 
Firstly, the parents were asked how they describe STEM education. Three out of five parents replied: "I cannot know exactly since it was not explained to us in detail". One parent described it as "coming with a solution to real-life problems and creating a product by using real-life materials directed to the goal". In addition, another parent defined it as "an education trend integrated with the disciplines of science, engineering and mathematics". Some sample expressions of the parents are as follows:

"Honestly, I am not sure about its content since it is just written on the paper, and that is all we know. They did not provide us with information in detail." (MD1) "...it is a goal-directed method for finding a creative solution to problems in real life. It seems to me that it is to create a goal-directed product by using real-life materials." (MD2)

When the parents were asked about thoughts on STEM education, all of the parents said they "do not have any thoughts since the schools did not inform them and the children did not talk about this topic".

"I know the practices are being carried out, but I do not have any exact thoughts. They did not tell us what will be done. My son does not tell me such things, anyway." (MS3)

"I do not know, and my son did not tell me anything about it." (FS2)

At the end of the STEM education, parents were asked if they had observed any changes in their children. Four parents stated that they had observed a change, but they were not sure if the change was due to STEM education, while one parent said that they had not observed any changes.

"I cannot be sure if changes are due to STEM education or other school practices. Maybe his teacher realized something, but I was not informed about which changes my child should exhibit." (FS1)

"I have not observed such a change." (MD2)

Lastly, when parents were asked about general ideas on STEM education, all the parents stated that it is necessary to be informed about content of education. Moreover, four out of five parents demanded "sharing the expected outcomes", while one parent wanted to know "how to support the education at home". Some statements from the parents are as follows:

"...they could have informed us about the education. I want to know the purpose of the education, what changes it leads to or what I should do to support my child. It could be better." (MS3)

"If they had informed us what they would do for STEM education or how to do it, we would have observed our children accordingly. I do not know the outcomes of STEM education or which behaviour my child should acquire due to STEM education." (MD1) 


\section{Interview with the teacher Implementing STEM education}

Teachers implementing STEM education were interviewed after each practice. After each practice (the total number 16) for eight weeks, the teacher was interviewed on STEM practice of that day.

Firstly, the question "Why was the practice implemented well?" was asked, and answers of the teacher were indicated in Table 2.

Table 2

Answers of Teachers to the Question "why was the practice implemented well?"

\begin{tabular}{lll}
\hline Category & F & $\%$ \\
\hline Goal-oriented application & 11 & 44 \\
Classroom Management & 4 & 16 \\
Attention & 4 & 16 \\
Evaluation & 3 & 12 \\
Linked with their past learning & 2 & 8 \\
Entertainment-oriented & 1 & 4 \\
Total & 25 & 100
\end{tabular}

In Table 2, the teacher stated that 11 out of 16 practices were goal-oriented, four practices managed to arouse attention and keep the class attentive, three practices were able to evaluate students, two practices were linked to their past learning experiences, and one practice was entertainment-oriented.

"During the process, they enjoyed and focused. I did not force them..." (IT- $1^{\text {st }}$ Implication)

"This week, classroom management was good. We decided on the rules, and they seemed to obey... It was good to apply evaluation part." (IT- $3^{\text {rd }}$ Implication) "The outcome stated in the purpose was emphasized more than once." (IT-12 $2^{\text {th }}$ application)

Answers from teachers for the same practice to the question "Why was the practice implemented badly?" are shown in Table 3.

Table 3

Answers of Teachers to the Question "Whi was the practice implemented badly?"

\begin{tabular}{llc}
\hline Category & $F$ & $\%$ \\
\hline Classroom management problems & 7 & 33.33 \\
Inadequate materials & 5 & 23.81 \\
Limited time & 4 & 19.05 \\
Lack of preparation of teachers for their class & 4 & 19.05 \\
Probability of misconception & 1 & 4.76 \\
Total & 21 & 100 \\
\hline
\end{tabular}

In Table 3, teachers stated that seven out of 16 practices failed because of unsuccessful classroom management, five practices failed due to a lack of materials, four practices 
failed due to limited time and lack of teachers' preparation, and one practice might lead to misconception; therefore, it could not be implemented well.

"Practices were challenging since they consist of scientific processes which are hard to animate such as the fact that the wind is produced by uneven heating. I tried my best to conceptualize the process but I am not sure if it worked. It should be re-done more than once." (IT- $7^{\text {th }}$ Practice)

"30 minutes for the practice made the implementation hard. Before the implementation, there should have been some experience and information. However, at that moment, it is beyond reality to provide information and expect the product." (IT- $2^{\text {nd }}$ Practice)

Lastly, Table 4 shows answers of teachers implementing STEM practices to the question "What would you change if you applied the practice again?".

Table 4

Answers of Teachers to the Question "What would you change if you applied the practice again?"

\begin{tabular}{lll}
\hline Category & F & $\%$ \\
\hline I would vary materials. & 9 & 42.84 \\
I would extend time. & 2 & 9.53 \\
I would increase the number of already applied materials. & 2 & 9.53 \\
I would combine practices. & 2 & 9.53 \\
I would use concepts carefully. & 2 & 9.53 \\
I would specify classroom rules. & 1 & 4.76 \\
I would collaborate with other teachers. & 1 & 4.76 \\
I would add different concepts. & 1 & 4.76 \\
I would give priority to group work. & 1 & 4.76 \\
Total & 21 & 100 \\
\hline
\end{tabular}

As shown in Table 4, if teachers reapplied the sixteen practices, they would vary materials for 9 practices, they would extend time and the number of materials, combine practices and use concepts carefully, specify classroom rules, collaborate with other teachers, add some new concepts to the practices and give priority to group work.

"We could talk to other two colleagues before the practice. I had some questions on my mind, but they did not know." (IT- $1^{\text {st }}$ Practice)

"... During the implementation, I used "heavy" and "light" rather than "small" and "big". I could have paid more attention to my word choices. This situation might lead to misconceptions in the future." (IT-13 $3^{\text {rd }}$ Practice)

"Maybe, I may give students an opportunity to work in groups with 2-3 people, and give each one hot and cold water cups." (IT-14 $4^{\text {th }}$ Practice)

\section{Interviews with the teachers}

In Semi-Structured Interview (B) Forms, teachers were asked some questions about the definition of STEM education, the STEM education applied and the observed changes in children after STEM education had been implemented. 
Firstly, teachers were asked what STEM education means to them. Two teachers stated that STEM education involves different disciplines. Furthermore, one teacher said STEM education provides children with different viewpoints, while another teacher mentioned that STEM education gives opportunity to find a solution to problems, and create a product based on the solution.

"Children can create different ways to think thanks to STEM education. While building a ship or other things, they do not simply do similar designs; they can create original things thanks to different viewpoints." (CT)

"...we can describe STEM education as offering a possible solution by using engineering and technological skills and taking scientific and mathematical topics into consideration for real-life problems or a problem that a teacher assigns." (IT)

When teachers were asked about their thoughts on STEM education they were applying, one teacher explained it as a systematic education involving different experiences and perspectives, and creating different viewpoints. Another teacher emphasized that STEM education provides children with concepts, learning during the process and learning it experience.

"Apart from their form teacher, to have other people in the classroom and produce something together was a valuable experience... You brought different perspectives to children." (CT)

"All of the practices were aimed at different purposes. In general, there were practices to increase the readiness level of children. We learnt, experienced and observed concepts about science and mathematics together. All the practices were aimed at different purposes." (IT)

Teachers were asked why they found STEM education interesting, and they stated that they were already interested in science and mathematics, they had taken some educational seminars on the topic, STEM education became popular and STEM education would contribute to the future.

"...when you see the name everywhere, you are becoming curious as a teacher. Also, its potential to shape the future is increasing my curiousness more." (CT)

"I have always loved science. Academically, I am also involved in it. My mathematical skills are also good, coming from the past." (IT)

Teachers were also asked if they saw any change in children after STEM education. 2 teachers stated that they observed some improvement in children in some fields such as creativity, expressing themselves, observing from different perspectives, mathematics (ordering and categorizing) and being aware of the relationship between reason and result. Furthermore, teachers stated that STEM education enabled children to become more curious, easy-going, and it improved their awareness of different materials.

"It affected children positively. They became curious about its purpose and result. They discovered the benefit of group work. They acquired concepts such as categorizing and ordering." (CT) 
"There was a huge difference between the first and last practice. I observed changes in their creativity. They improved different viewpoints... They became more self-expressed. They looked at phenomena from different perspectives and produced some solutions." (IT)

Lastly, teachers emphasized the role of teachers in STEM education, and necessity of educational seminars for teachers when they were asked about their general opinions on STEM education. Another teacher shared their concerns about the fact that STEM education might be monotonous if it is applied consistently, and this could impede improvement of education.

"What if we repeat ourselves again and again?" (CT)

"In STEM education, teachers are really important since STEM education does not mean providing direct information; it aims to make students discover information by themselves." (IT)

\section{Interviews with vice-principals}

Vice-principals were interviewed with five different questions on STEM education implemented in the classroom.

When vice-principals were asked what STEM education means to them, they answered this question with the word "curiosity". Another vice-principal defined it as "project-based education involving engineering, art, science and mathematics with lots of perspectives".

"I can describe it as a project-based education involving engineering, art, science and mathematics with lots of perspectives." (VP1)

"It is to make children curious, to change their imagination and make them see different things. It is not a simple acronym; it is to satisfy children's curiosity, and make them feel satisfied." (VP2)

When vice-principals were asked about their opinions about the STEM education they observed, one of them said: "It made our school known, and we got positive feedback from parents", while another stated that "it is based on producing solutions, and it is a different education type". Moreover, they said the exhibition at the end of education was also visited by children of different age groups, and the parents of these children also became interested in STEM.

"It was a good opportunity for both parents and us; that would make our school known around neighbourhood. After children presented their projects, parents gave us positive feedback." (VP1)

"It was a wonderful experience for us, and a really different practice. The focus is on producing solutions, and I think we should continue it." (VP2)

After STEM education, vice-principals expressed their observation of positive changes in students. Children were successful in expressing original opinions and finding 
solutions to problems, and they could ask more questions. Moreover, they observed some positive changes in the form teachers too. During the process of education the teachers became more productive, inquisitive, supportive and took initiative.

"For the tiniest thing, they say we can create something creative by using it. The other day they produced a thing with magnet. They were using it as a garbage collector and collected garbage from the floor." (VP1)

"...before the education they were just interested in their toys, but now they are planning to and are interested in building a book." (VP2)

"Yes, the teacher always comes up with new projects. S/he demands new materials from parents. They are dealing with projects...." (VP1)

"... since the teacher notices attention of children in that way, s/he starts to ask more questions to spark their curiosity..."(VP2)

Lastly, vice-principals expressed their positive reactions towards STEM education. They were willing to apply the same practice with students in different age groups and maintain the practice throughout the year.

"...I hope students of all age groups can benefit from that education. I hope we can do it throughout the school year..." (VP1)

"We want to make that education consistent in our school so that we can improve and support curiosity of our students...”(VP2)

\section{Discussion}

During the STEM education in this research, 39 out of 48 indicators were observed by using The Classroom Observation Protocol (COP). In the study by Tippett and Milford (2017), 41 out of 48 indicators were observed, and this finding showed that STEM education had 41 components of effective practices. Therefore, it was recommended to implement STEM education in early childhood. Similarly, the fact that 39 out of 48 indicators were observed shows that STEM education has achieved the expected educational goals, it can be implemented in teaching young learners and in teaching young learners and appropriataely incorporated in early childhood classrooms. Moreover, all indicators of eight sub-dimensions were observed, characteristics and nature, constructing, observing, describing, categorizing, communicating, analysing and interpreting, explaining and designing solutions. Therefore, the outcomes of these sub-dimensions and requisites of STEM education are emphasized with this study. 2 out of 3 indicators of 7 sub-dimensions were also observed, patterns and interactions, pretending, socio-dramatic, exploring surroundings, predicting, questions and problems, math and computational thinking. This finding indicates that outcomes of sub-dimensions and requisites of STEM education were mentioned during the process while educational program aiming at these sub-dimensions should be supported. Lastly, only one indicator of the sub-dimension "argument" was observed. Therefore, 
it is necessary to revise and enrich the educational program of the sub-dimension "argument". The Classroom Observation Protocol (COP) seems to be a guide for the advocates of STEM education's implementation. While preparing educational programs and lesson plans of STEM for young learners, it might be beneficial to use this protocol as guidance so that inclusion of STEM into the educational program could be improved, and that teachers could observe the learning process better. Furthermore, the findings of the study might be a guide for teachers to form educational programs and lesson plans which include all the factors of STEM education. Based on these results, STEM education, which emphasizes the importance of education of young learners, should be included in educational policies aiming at young learners and it should be implemented.

According to this study, parents are not informed enough about STEM education. That might affect ideas and opinions of parents towards STEM education. Parents stated that they did not know what STEM education means, and they could not find any connection between STEM education and the observations of curiosity, asking more questions, focusing on solutions and showing an increasing interest in Mathematics they had observed in their children. Akgunduz and Akpinar (2018) emphasized in their study that they could not observe any positive changes in $21^{\text {st }}$ century skills, curiosity and motivation of children. As stated in the related literature, according to the study by Tippett and Milford (2017), parents demanded information on STEM education. This finding by Gulgun et al., (2017) showed that informing parents about STEM education might contribute to educational process, which supports the current study. That means that lack of information might prevent parents from getting necessary information on STEM education. Future studies might focus on involving parents in the educational process by arranging informative seminars.

According to teachers that implemented STEM education, the fact that the practice was goal-oriented, good for classroom management, and made possible to evaluate and entertain students showed that it was implemented well. The related literature also supports the finding that practices of STEM education are goal-oriented (Akgunduz \& Akpinar, 2018). Parts not implemented well were classroom management problems, insufficient materials, limited time, inadequate preparation of teachers and probability of misconceptions. Limited time for the practice is also mentioned in the related literature (Ugras, 2017). Moreover, the teacher stated that she would enrich materials, extend time of practice, increase the number of materials, make connections between practices, use concepts carefully, specify classroom rules, collaborate with other teachers, add some new concepts and prioritize group work if she applied the practice again. The teacher might notice the parts which did not work well during the practice and believes that she could improve her work in the future practices, which indicates that the teacher is open to improvement and good at observing her deficiencies. Constituting a chart for implementers of STEM education to evaluate themselves at the end of an educational process might be beneficial for dealing with difficulties. Similarly, COP 
(Tippett \& Milford, 2017) might be also used by teachers, and they might observe the number of STEM factors included in the educational activity to fulfil the criteria necessary for STEM education.

During interviews with the teachers, they stated that STEM education includes different disciplines, as supported in the related literature (Akgunduz et al., 2015; Aydagul \& Terzioglu, 2014; Balat \& Gunsen, 2017; Breiner et al., 2012). Furthermore, according to those teachers, STEM education provides children with different viewpoints and experiences, and it supports teaching of concepts by experiencing the process, the skill of problem-solving, and producing something based on the solution. These findings are supported by studies conducted by Akgunduz and Akpinar (2018), Basaran (2018) and Yildirim and Turk (2018). Teachers attributed their interest in STEM education to their past interest in science and mathematics, past educational seminars they had taken, popularity of STEM education and potential to contribute to education in the future. Future studies might focus on teachers' attitudes and awareness of STEM education.

Teachers observed some changes in children as a result of STEM education. Children improved their creativity, self-expression skills, perspectives, mathematical skills (ordering, categorizing), and cause and effect awareness. Furthermore, they stated that children had become more curious and harmonic, and they had improved their awareness of using different materials. Those findings seem consistent with the findings of the related national and international literature (Akgunduz \& Akpinar, 2018; Basaran, 2018; Tippett \& Milford, 2017; Ugras, 2017; Yildirim, \& Turk, 2018).

Teachers thought that educational seminars on STEM education aimed at teachers are necessary, so that they can use STEM education in their own lessons, prepare effective materials and support students during the process. Those findings are supported by the study conducted by Ozbilen (2018). Furthermore, in the study of Akgunduz and Akpinar (2018), they emphasized the importance of recognizing correct materials and using them for development of children, which means that recognizing correct materials and introducing them is critical for this development. Moreover, they shared their fear that STEM education may become monotonous when it is implemented all the time in the classroom. To prevent that problem, teachers might be provided with in-service training, they might attend seminars and share their knowledge and experience on STEM practices on the platform, which is consistent with the related literature (Gulgun et al., 2017).

Interviews with vice-principals are a novel part in the STEM literature. Tippett and Milford (2017) suggested that it might be beneficial to conduct interviews with school principals. Interviews with vice-principals described STEM education as a projectbased education involving engineering, art, science and mathematics with lots of perspectives, and they said that it arouses curiosity of children. They also got positive feedback from parents of students, which is consistent with the study of Basaran (2018). These findings indicate that school principals give importance to making their schools known for different activities. Vice-principals also observed positive changes 
in children and teachers. For example, students became more successful in coming up with original ideas, producing efficient solutions, arousing their curiosity and asking more questions. Teachers also became more productive, inquisitive, supportive and took initiative. The positive feedback indicates that vice-principals are satisfied with STEM education, and they are willing to implement it with children of all ages. Viceprincipals might be provided with some in-service training and seminars so that STEM education can be prevalent among teachers.

\section{Conclusion}

In this study, 39 out of 48 indicators necessary for STEM education's implementation in early childhood were observed. Thus, it might be said that the STEM education applied in has the possible characteristics of STEM education in early childhood, and can be appropriately incorporated into early childhood classes. Tippett and Milford (2017) stated in their study which indicators are necessary to be included in STEM education in early childhood, by using The Classroom Observation Protocol (COP). As the number of indicators observed in the protocol increased, it was emphasized that the STEM education applied has the characteristics of STEM education in early childhood. 41 out of 48 indicators were observed, and this finding showed that the applied STEM education had 41 components of effective practices. Therefore, STEM education can be implemented in early childhood, which is similar to the findings of this study in this context.

In addition, it was emphasized emphasized in the interviews with teachers and school principals that STEM education implemented provides positive effects on children's development by creating different perspectives for children. However, the interviews with parents are the limitation of this study. Out of 15 children, only 5 parents in the experimental group participated in this study, and those parents stated that they did not have information about the STEM education implemented or STEM education in general. Therefore, sufficient data could not be obtained in the part of the study conducted with families. In future studies more information could be obtained from families with regards to STEM education in early childhood.

\section{References}

Aldemir, J., \& Kermani, H. (2017). Integrated STEM curriculum: improving educational outcomes for Head Start children. Early Child Development and Care, 187(11), 1694-1706. https://doi.org/10.1080/03004430.2016.1185102

Akgunduz, D., Aydeniz, M., Cakmakci, G., Cavas, B., Corlu, M. S., Oner, T., \& Ozdemir, S. (2015). A report on STEM Education in Turkey: A provisional agenda or a necessity? Scala Basim.

Akgunduz, D., \& Akpinar, B. C. (2018). Evaluation of STEM applications based on science education in pre-school education in terms of students, teachers and parents. Journal of Education for Life, 32(1), 1-26. 
Arikan, E. E. (2018). A theoretical study on STEM education: proposal of two applications. Journal of Theoretical Educational Science, 11(1).

Aydagul, B., \& Terzioglu, T. (2014). The importance of science, technology, engineering and mathematics! https://www.tusiadstem.org/kesfet/makaleler/2-bilim-teknoloji-muehendislikve-matematigin-oenemi

Aydeniz, M. (2017). Eğitim sistemimiz ve 21. yuzyıl hayalimiz: 2045 hedeflerine ilerlerken, Türkiye için STEM odaklı ekonomik bir yol haritası (Our education system and $21^{\text {st }}$ Century dream: STEM-oriented economic road map for Turkey by going towards 2045 target). Resource document. University of Tennessee, Knoxville. http://www.psych.org/edu/other res/lib archives/archives/200604.pdf

Ata Akturk, A., Demircan, H. O., Senyurt, E., \& Cetin, M. (2017). Turkish early childhood education curriculum from the perspective of STEM education: a document analysis. Journal of Turkish Science Education (TUSED), 14(4), 16-34.

Bahar, M., Yener, D., Yilmaz M., Emen, H., \& Gurer, F. (2018). The changes of standards in the 2018 science curriculum and STEM integration. Abant İzet Baysal University Journal of Faculty of Education, 18 (2), 702-735. https://doi.org/10.17240/aibuefd.2018..-412111

Balat, G. U., \& Gunsen, G. (2017). STEM approach in pre-school period. The Journal of Academic Social Science, 5(42), 337-348. https://doi.org/10.17240/aibuefd.2018..-412111

Bakirci, H., \& Kutlu, E. (2018). Determination of science teachers' views on STEM approach. Turkish Journal of Computer and Mathematics Education, 9(2), 367-389. https://doi. org/10.16949/turkbilmat.417939

Basaran, M. (2018). A Research on the Applicability of STEM Approach in Preschool Education. (Unpublished dissertation). Gaziantep, Turkey: Gaziantep University.

Breiner, J. M., Harkness, S. S., Johnson, C. C., \& Koehler, C. M. (2012). What is STEM? A discussion about conceptions of STEM in education and partnerships. School Science and Mathematics, 112(1), 3-11. https://doi.org/10.1111/j.1949-8594.2011.00109.x

Bolatli, Z., \& Korucu, A. Z. (2018). Secondary school students' feedback on course processing and collaborative learning with web 2.0 tools-supported STEM activities. Bartin University Journal of Faculty of Education, 7(2), 456-478. https://doi.org/10.14686/buefad.358488

Buyukozturk, S., Kilic Cakmak, E., Akgun, O. E., Karadeniz, S., \& Demirel, F. (2016). Bilimsel araştırma yöntemleri (Research methods). Ankara, Turkey: Pegem Akademi. https://doi. org/10.14527/9789944919289

Bybee, R.W. (2010). What is STEM education?. Science, 329(5995), 996. https://doi.org/10.1126/ science. 1194998

Cetinkaya-Aydin, G., Sicim Sevim, B., \& Yilmaz, S. (2017, August). STEM instruction in the early childhood classroom: a case from Turkey [abstract]. In European Conference on Educational Research. Copenhagen: Campus Carlsberg: University College UCC. https://eera-ecer.de/ ecer-programmes/conference/22/contribution/41416/

Cotabish, A., Dailey, D., Robinson, A., \& Hughes, G. (2013). The effects of a STEM intervention on elementary students' science knowledge and skills. School Science and Mathematics, 113(5), 215-226. https://doi.org/10.1111/ssm.12023

Creswell, J.W. (2014). Research design: Qualitative, quantitative, and mixed methods approaches. Sage Publications. 
Deveci, I. (2018). The STEM awareness as predictor of entrepreneurial characteristics of prospective science teachers. Kastamonu Education Journal, 99(99), 1-18. https://doi. org/10.24106/kefdergi.346652

Erdogan, I., Ciftci, A., Yildirim, B., \& Topcu, M. S. (2017). STEM Education practices: examination of the argumentation skills of pre-service science teachers. Journal of Education and Practice, 8(25), 164-173.

Gulgun, C., Yilmaz, A., \& Caglar, A. (2017). Teacher opinions about the qualities required in STEM activities applied in the science course. Journal of Current Researches on Social Sciences, 7(1), 459-478.

Gokbayrak, S., \& Karisan, D. (2017). Investigating the effect of STEM based laboratory activities on preservice science teacher's STEM awareness. Journal of Human Sciences, 14(4), 4275-4288. https://doi.org/10.14687/jhs.v14i4.5017

Ince, K., Misir, M. E., Kupeli, M. A., \& Firat, A. (2018). Examining the effect of STEM-based approach on the problem solving ability and academic success of students in teaching the enigma of the Earth's crust unit of the 5th grade life sciences course. Journal of STEAM Education, 1(1), 64-78.

Johnson, B., \& Christensen, L. (2014). Educational research: Quantitative, qualitative, and mixed approaches (Translate Ed. SB DEMİR). Eğiten Kitap.

Kelley, T. R., \& Knowles, J. G. (2016). A conceptual framework for integrated STEM education. International Journal of STEM Education, 3(1), 11. https://doi.org/10.1186/ $\underline{\text { s40594-016-0046-Z }}$

Kennedy, T. J., \& Odell, M. R. L. (2014). Engaging students in STEM education. Science Education International, 25(3), 246-258.

Lester, S. (1999). An introduction to phenomenological research. Stan Lester Developments. https:// www.researchgate.net/profile/Stan Lester/publication/255647619 An introduction to phenomenological research/links/545a05e30cf2cf5164840df6.pdf

Milford, T., \& Tippet, C. (2015). The design and validation of an early childhood STEM classroom observational protocol. International Research in Early Childhood Education, 6(1), 24-37.

Moomaw, S., \& Davis, J. A. (2010). STEM comes to preschool. Young Children, 65(5), 12.

Ozbilen, A. G. (2018). Teacher opinions and awareness about STEM education. Scientific Educational Studies, 2(1), 1-21.

Park, S. J., \& Yoo, P. K., (2013). The effects of the learning motive, interest and science process skills using the "light" unit in science-based STEM. Elementary Science Education, 32(3), 225-238.

Robinson, N. (2016). A case study exploring the effects of using an integrative STEM curriculum on eighth grade students' performance and engagement in the mathematics classroom. (Dissertation). Atlanta: Georgia State University.

Ross, J. A., \& Gray, A. H. (2012). Integrating mathematics, science, and technology: Effects on students. International Journal of Science Education, 4(2), 89-101.

Sanders, M. E. (2009). Stem, stem education, stemmania. The Technology Teacher, 68(4), 20-26.

Soylu, R. A. S. (2016). STEM education in early childhood in Turkey. Journal of Educational and Instructional Studies in The World, 6(1), 38-47. 
Tippett, C. D., \& Milford, T. M. (2017). Findings from a Pre-Kindergarten classroom: Making the case for STEM in early childhood education. International Journal of Science and Mathematics Education, 15(1), 67-86. https://doi.org/10.1007/s10763-017-9812-8

Ugras, M. (2017). Preschool teachers' views about STEM applications. The Journal of New Trends in Educational Sciences, 1(1), 39-54.

Ugras, M., \& Genc, Z. (2018). Investigating preschool teacher candidates' STEM teaching intention and the views about STEM Education. Bartin University Journal of Faculty of Education, 7(2), 724-744. https://doi.org/10.14686/buefad.408150

White, D. W. (2014). What is STEM education and why is it important. Florida Association of Teacher Educators Journal, 1(14), 1-9.

Yasar Ekici, F., Bardak, M., \& Zadeh, M. Y. (2018). Erken Çocukluk Döneminde STEM (STEM in Early Childhood). In K.A. Kırkıcc \& E. Aydın (Eds.), Merhaba STEM: Yenilikçi Bir Öğretim Yaklaşımı (STEM: An Innovative Teaching Approach) (pp. 51-79). Eğitim Yayınevi.

Yildirim, A., \& Şimşek, H. (1999). Sosyal bilimlerde nitel araştırma teknikleri (Qualitative research methods in social sciences). Seçkin Yayınları.

Yildirim, B., \& Turk, C. (2018). Pre-Service primary school teachers' views about STEM education: An applied study. Trakya University Journal of Education Faculty, 8(2), 195-213.

\section{Remziye Ceylan}

Department of basic education

Faculty of Education

Yıldız Technical University

Yıldız Teknik Üniversitesi, Davutpaşa Kampüsü,

Eğitim Fakültesi, A-308, Esenler, İstanbul, Turkey

rceylan@yildiz.edu.tr

\section{Beyza Akçay Malçok}

Department of basic education

Faculty of Education

Yıldız Technical University

Yıldız Teknik Üniversitesi, Davutpaşa Kampüsü,

Eğitim Fakültesi, A-308, Esenler, İstanbul, Turkey

bakcay@yildiz.edu.tr 


\section{Provedba STEM nastave u ranoj dobi i mišljenja svih dionika: primjer Turske}

\section{Sažetak}

Cilj ovoga rada bio je promatrati i ispitati provedbu STEM nastave u ranoj dobi i saznati mišljenja nastavnika, roditelja i školskoga rukovodstva o tome. Metoda korištena u istraživanju je analiza slučaja, koja je jedna od kvalitativnih metoda istraživanja. Podatci su prikupljeni pomoću Protokola promatranja nastave i polustrukturiranih intervjua s roditeljima, nastavnicima i zamjenicama ravnatelja. Istraživanje je provedeno u Turskoj, u predškolskoj obrazovnoj ustanovi u sklopu državnoga sveučilišta u Istambulu. U istraživanju je sudjelovalo 15 djece, dva nastavnika, dvije zamjenice ravnatelja i petero roditelja. Podatci su opisani pomoću metode analize sadržaja. Tijekom provedbe STEM nastave, pomoću Protokola promatranja nastave promatrano je 39 od ukupno 48 indikatora. Zaključeno je da provedena STEM nastava sadrži potrebne odrednice STEM područja te da se STEM nastava može na odgovarajući način provoditi i u nastavi u ranoj životnoj dobi. Pomoću rezultata dobivenih putem intervjua zaključeno je da roditelji nisu imali potrebne informacije o STEM nastavi jer im nije bilo pruženo dovoljno informacija. Nastavnici i zamjenice ravnatelja bili su zadovoljni takvom nastavom te su kod djece primijetili pozitivne promjene kao rezultat provedbe STEM nastave.

Ključne riječi: inženjerstvo; matematika; STEM; rana dob; tehnologija; znanost

\section{Uvod}

STEM je pristup koji obuhvaća područja znanosti, tehnologije, inženjerstva i matematike (Breiner, Harkness, Johnson i Koehler, 2012). Ranih 1990-ih Nacionalna znanstvena fondacija u Turskoj koristila je akronim SMET za „znanost, matematiku, inženjerstvo i tehnologiju" (Breiner i sur., 2012; Sanders, 2009). Međutim, taj se akronim, kao i ostali termini, mijenjao tijekom vremena i 2001. godine postao STEM. Najbitniji je dio STEM nastave pronaći rješenja za probleme u području inženjerstva koristeći znanja iz područja znanosti i matematike, uz podršku tehnologije (Kennedy i Odell, 2014). Jedan od ciljeva STEM nastave je doprinijeti ekonomskom razvoju zemalja i stvoriti radnu snagu koja tom razvoju pomaže (Kelley i Knowles, 2016; Sanders, 2009).

Sastavnice STEM-a omogućavaju nova otkrića, posebno u industriji (White, 2014). Prepoznata su zanimanja koja uključuju sastavnice STEM-a i koja omogućavaju 
inovacije te je potreba za tim zanimanjima sve veća (Aydagul i Terzioglu, 2014). K tomu, prevladava mišljenje da STEM nastava na bolji način obrazuje i nastavnike i učenike te stvara raznovrsne prilike za zaposlenje (Breiner i sur., 2012). Stvaranje kvalificirane radne snage zahtijeva obrazovne programe koji u sebi imaju integrirane vještine 21 . stoljeća. Stoga je jako važno u obrazovne programe unijeti novu perspektivu tako što će se postojeći obrazovni programi preispitati. Nova perspektiva može biti moguća tako što će se discipline STEM-a i STEM nastava uklopiti u postojeće obrazovne programe jer je STEM pristup koji ima za cilj pronaći rješenja za probleme primjenom znanstvenih metoda i koji naglašava važnost individualnih i kolaborativnih načina rada. U takvom pristupu znanost, tehnologija, inženjerstvo i matematika imaju važnu ulogu u razvoju mnogih vještina 21. stoljeća, kao što su rješavanje problema, kreativnost, suradnja, analitičko mišljenje i komunikacijske vještine. Stoga će uključivanje STEM nastave u postojeće obrazovne programe pomoći razvoju vještina 21. stoljeća kod učenika, a takve vještine tražene su u zemljama koje imaju interdisciplinarno stajalište o STEM nastavi (Erdogan, Ciftci, Yıldırım i Topcu, 2017). Razvoj vještina 21. stoljeća kod učenika usko je povezan s važnosti novih obrazovnih programa na svim razinama obrazovanja, počevši od rane dobi.

Već od rane dobi djeca postavljaju pitanja, promatraju, istražuju, predviđaju i traže rješenja, poput znanstvenika. Važno je poticati dječju znanstvenu znatiželju već u ranoj dobi kako bi se djeca usmjeravala prema istraživačkom radu u budućnosti (Aydagul i Terzioglu, 2014; Genc-Kumtepe, Kaya, Erdogan, Alan i Kumtepe, 2017). Dakle, znatiželja u ranom djetinjstvu održavat će interes djece za znanost i matematiku i omogućiti im da postanu uspješni znanstvenici u budućnosti (Soylu, 2016). U provedenim studijama uočeno je da provedba STEM nastave u ranoj dobi pozitivno utječe na razvoj djece (Aldemir i Kermani, 2017; Balat i Gunsen, 2017; Milford i Tippet, 2015; Moomaw, 2013). Tippett i Milford (2017) u svojem su istraživanju naglasili da su djeca jako zainteresirana za STEM nastavu u ranoj dobi i da su voljna učiti izvan učionice upravo zbog takve vrste obrazovanja. Osim toga, Aldemir i Kermani (2017) u svojem su istraživanju istaknuli da provedba STEM nastave u ranoj dobi i njezino uključivanje u obrazovni program imaju pozitivan utjecaj na razvoj sljedećih vještina kod djece 21 . stoljeća: rješavanje problema, kreativno mišljenje i analiziranje.

\section{STEM nastava i mišljenje dionika}

STEM zauzima sve važnije mjesto na svim razinama obrazovanja. Zanimanja koja se temelje na STEM-u i edukacija ljudi u području vještina koje su neophodne za ta zanimanja bitni su za razvoj svih zemalja. U tome bi smislu STEM nastava trebala biti uključena u obrazovne programe od ranoga djetinjstva do fakultetske razine obrazovanja (Aydagul i Terzioglu, 2014; Breiner i sur., 2012; Bybee, 2010). Iako je praksa STEM nastave od velike važnosti u osnovnoškolskom, srednjoškolskom i visokom obrazovanju (Bolatlı i Korucu, 2018; Cotabish, Dailey, Robinson i Hughes, 2013; Deveci, 2018; Gokbayrak i Karisan, 2017; İnce, Misır, Kupeli, i Firat, 2018; Park i Yoo, 2013; Ross i 
Gray, 2012; Robinson, 2016; Yıldırım i Turk, 2018), provedba STEM nastave u ranoj dobi stvar je interesa. U Turskoj se o tome postavlja puno pitanja, posebno o provedbi takve nastave pa je do sada provedeno više istraživanja (Akgunduz i Akpinar, 2018; Balat i Gunsen, 2017; Basaran, 2018; Cetinkaya-Aydin, Sicim Sevim i Yilmaz, 2017).

U nekim je istraživanjima istaknuto da program predškolskoga obrazovanja u Turskoj sadrži sastavnice STEM nastave (Akgunduz i sur., 2015; Ata Akturk, Demircan, Şenyurt i Çetin, 2017; Basaran, 2018). U tom se programu discipline STEM-a vrednuju zasebno, ali STEM nastava treba biti integrirana u postojeći program, uz interdisciplinarni pristup (Ata Akturk i sur., 2017; Aydagul i Terzioglu, 2014; Soylu, 2016). Basaran (2018) je također proveo istraživanje o prikladnosti važećih obrazovnih programa i fizičkih preduvjeta za STEM nastavu. U njegovom istraživanju došlo se do zaključka da nema dovoljno fizičkih materijala za rad u razredu neophodnih za provedbu STEM nastave u predškolskim obrazovnim ustanovama, da nastavnici imaju pozitivne stavove o STEM nastavi te da je STEM nastava imala pozitivan utjecaj na djecu koja su je iskusila, pogotovo kada se radi o predstavljanju proizvoda, radu u grupama i vještinama kognitivnoga inženjerstva. $U$ istome se istraživanju ističe da je STEM nastava prikladna za djecu rane dobi i da se u toj dobi može provoditi.

Također je važno promatrati i ispitati sadrže li aktivnosti koje se provode u sklopu STEM nastave sve sastavnice STEM-a. Protokol za promatranje nastave izradili su Milford i Tippet (2015), a Cetinkaya-Aydin, Sicim Sevim i Yilmaz (2017) preveli su ga na turski jezik. Tako su ujedno pružili potporu istraživanjima koja se bave promatranjem i objašnjavanjem STEM nastave u Turskoj. Zaključak je da je STEM nastava provedena uz primjenu ovoga protokola od velike važnosti za istraživanja koja se fokusiraju na rano djetinjstvo (Cetinkaya-Aydin, Sicim Sevim i Yilmaz, 2017; Tippett i Milford, 2017).

Osim promatranja provedbe STEM nastave i njezine procjene pomoću protokola, od velike su važnosti bila i stajališta svih dionika (roditelja, nastavnika i djece). Njihova su mišljenja uključena $\mathrm{u}$ istraživanja u kojima se ispitivala STEM nastava (CetinkayaAydin, Sicim Sevim i Yilmaz, 2017; Tippett i Milford, 2017; Akgunduz i Akpinar, 2018; Basaran, 2018). Tippet i Milford (2017) u svojem su istraživanju pokazali da roditelji imaju pozitivan stav o STEM nastavi i da su kod svoje djece primijetili pozitivne promjene. Nastavnici su također imali pozitivne stavove o STEM nastavi pa se došlo do zaključka da je takvo obrazovanje jako važno u ranom djetinjstvu. $\mathrm{K}$ tomu, zaključak je i da je STEM nastava neophodna i da bi se trebala provoditi. Međutim, ona ipak predstavlja neke dodatne obveze za nastavnike, iako pozitivno utječe na razvoj učenika (Akgunduz i sur., 2015; Basaran, 2018; Ugras, 2017; Ugras, i Genc, 2018). Akgunduz i Akpinar (2018) pomoću provedenih intervjua uočili su da STEM nastava potiče dječju znatiželju i motivaciju te da su djeca razvila kritičko mišljenje te suradničke i komunikacijske vještine. Moomaw i Davis (2010) smatraju da STEM nastava u ranoj dobi pomaže djeci usmjeriti pažnju i da razvija vještine rada u grupi. Basaran (2018) je došao do saznanja da uprava škole smatra da STEM nastava podiže status škole i osigurava povlastice nastavnicima i učenicima. Dakle, u ovim se istraživanjima 
naglašava, na temelju protokola promatranja i na temelju mišljenja dionika, da se STEM nastava može na odgovarajući način uklopiti u obrazovanje djece u ranoj dobi (Akgunduz i Akpinar, 2018; Basaran, 2018; Tippett i Milford, 2017). Ipak, uočeni su i neki nedostatci (Akgunduz i Akpinar, 2018; Basaran, 2018). Stoga bi trebalo obratiti pažnju na istraživanja koja se bave STEM nastavom, kako bi se detaljno ispitali nedostatci uočeni u prethodnim istraživanjima i dobila mišljenja o tome većega broja dionika. Međutim, u Turskoj ne postoji puno istraživanja provedenih u tom području. Dosadašnja istraživanja uglavnom ističu karakteristike STEM nastave (Arıkan, 2018; Aydeniz, 2017; Bahar, Yener, Yllmaz, Emen i Gürer, 2018; Yasar Ekici, Bardak i Zadeh, 2018), mišljenja nastavnika i budućih nastavnika o STEM nastavi (Bakırcı i Kutlu, 2018; Gulgun, Yllmaz i Caglar, 2017; Ozbilen, 2018; Ugras i Genc, 2018), potrebu za takvom nastavom te njezine pozitivne učinke na učenike u osnovnoj i srednjoj školi (Bolatlı i Korucu, 2018; Cotabish, Dailey, Robinson i Hughes, 2013; Deveci, 2018; Gokbayrak i Karisan, 2017; İnce, Misır, Kupeli i Fırat, 2018; Park i Yoo, 2013; Ross i Gray, 2012; Robinson, 2016; Ylldırım i Turk, 2018). Malobrojna su istraživanja o STEM nastavi u ranom djetinjstvu (Akgunduz i Akpinar, 2018; Balat i Gunsen, 2017; Basaran, 2018; Milford i Tippet, 2015; Tippett i Milford, 2017; Yasar Ekici, Bardak i Zadeh, 2018).

U ovom se istraživanju krenulo od sljedećih pitanja: Može li STEM nastava biti na odgovarajući način integrirana u obrazovanje djece u ranoj životnoj dobi? i Koja su mišljenja nastavnika, roditelja i uprave škole o aktualnoj STEM nastavi? Dakle, cilj je ovoga istraživanja promatrati i ispitati provedbu STEM nastave u ranom obrazovanju djece i provedbu takvoga obrazovanja promotriti sa stajališta raznih dionika - nastavnika, roditelja i uprave škole.

\section{Metode}

Analiza slučaja, kao jedna od kvalitativnih metoda istraživanja, odabrana je kao glavna metoda ovoga istraživanja. Analize slučaja provode se s ciljem promatranja detalja u jednoj ili više situacija, događaja, konteksta ili društvenih skupina koje se ispituju, a s ciljem pronalaženja objašnjenja za njih (Buyukozturk, Kılıç Çakmak, Akgun, Karadeniz i Demirel, 2016; Creswell, 2014; Johnson i Christensen, 2014). U ovom istraživanju cilj je bio saznati mišljenja sudionika postavljanjem općenitih ili specifičnih pitanja tijekom intervjua. $\mathrm{K}$ tomu, važno je sa sudionicima uspostaviti pozitivan odnos pun povjerenja tijekom tih intervjua te im omogućiti da eksplicitno izraze svoja mišljenja i tako daju detaljne informacije istraživačima (Lester, 1999). U ovom istraživanju, kako bi se promatrala i ispitala provedba STEM nastave, provedena su promatranja nastave i polustrukturirani intervjui s nastavnicima, roditeljima i upravom škole.

Istraživanje je provedeno u predškolskoj obrazovnoj ustanovi za djecu dobi između 3 i 6 godina, na državnom sveučilištu u Istambulu. Škola je otvorena prije dvije godine, a broj djece u skupinama kreće se između 9 i 15. Škola ima dva kata i veliki vrt te u njoj nastavu pohađa 97 djece. Ravnatelj, dvije zamjenice ravnatelja, savjetnik, devetero nastavnika i 5 članova osoblja za čišćenje zaposleno je u školi. Dob nastavnika varira 
između 22 i 40 godina, a njihovo radno iskustvo je između 4 i 20 godina staža. Svi nastavnici završili su srednju strukovnu školu za djevojke. Što se tiče onih koji su završili visoko obrazovanje, dvoje ih je diplomiralo na Odsjeku za predškolsko obrazovanje na Fakultetu za otvoreno obrazovanje, petero ih ima titulu stručnog pristupnika $u$ području dječjega razvoja, a jedan u području socijalnoga rada.

\section{Uzorak}

Istraživanje je provedeno na uzorku koji se sastojao od djece, nastavnika, zamjenica ravnatelja i roditelja. U istraživanje je bilo uključeno 15 djece iz vrtića i njihov nastavnik, odgojitelj koji je provodio STEM aktivnosti, dvije zamjenice ravnatelja u školi i 5 roditelja. Dob djece bila je u rasponu između 5 i 6 godina. Osim toga, ova su se djeca po prvi put susrela sa STEM praksom. Njihov je nastavnik završio diplomski studij predškolskoga odgoja, a radi u istoj školi 6 godina. Nastavnik koji je provodio STEM aktivnosti ima diplomu iz područja predškolskoga odgoja te pohađa magistarski studij. Uz to, završio je studij STEM nastave.

Dvije zamjenice ravnatelja u tim školama također su sudjelovale $\mathrm{u}$ istraživanju, a obje su završile program u području dječjega razvoja u srednjoj strukovnoj školi za djevojke. Jedna od njih ima 4, a druga 16 godina radnoga iskustva. Obje su po godinu dana radile $\mathrm{u}$ administraciji u svojim školama. Intervjuirani su i roditelji učenika - tri majke i dvojica očeva. Tih petero roditelja koji su sudjelovali u istraživanju imaju različite profesionalne profile - pripadaju administrativnom, akademskom i pomoćnom osoblju.

\section{Alati za prikupljanje podataka}

U ovom je istraživanju korišten Protokol promatranja nastave koji su izradili Milford i Tippet (2015), a pomoću njega su prikupljeni podatci o STEM nastavi i analizirana je ovakva vrsta nastave u Turskoj. Uz to, autor jeizradio i obrasce za polustrukturirane intervjue koji su korišteni za ispitivanje stavova sudionika o STEM nastavi. Kako bi odredili pitanja koja će biti postavljena u intervjuima, istraživači su proučili postojeću literaturu i konzultirali troje stručnjaka u relevantnim područjima - dvoje u području predškolskoga obrazovanja i jednoga u području STEM nastave. U istraživanju su korištena ukupno četiri obrasca za intervjue - Polustrukturirani intervju za roditelje, Polustrukturirani intervju za nastavnike - obrazac A i obrazac B te Polustrukturirani intervju za zamjenice ravnatelja.

\section{Protokol promatranje nastave}

Protokol promatranja nastave izradili su Milford i Tippet (2015). Svrha ovoga protokola je razumjeti sastavnice STEM nastave u ranom djetinjstvu i pomoći nastavnicima da STEM nastavu uključe u vlastiti nastavni proces. Uz to, protokol ispituje i sastavnice STEM nastave i njihovu učinkovitost $\mathrm{u}$ nastavi. Protokol se sastoji od 4 dimenzije, 16 poddimenzija i 48 pokazatelja. $\mathrm{K}$ tomu, u protokolu postoje tri pokazatelja za svaku poddimenziju. 
Dimenzije i poddimenzije izgledaju ovako: prva dimenzija: ispitivanje (poddimenzije: karakteristike i priroda, obrasci i interakcije); druga dimenzija: igra (poddimenzije: pretvaranje, društveno-dramska, konstruktivna, istraživanje okoline); treća dimenzija: vještine procesuiranja (poddimenzije: promatranje, opisivanje, kategoriziranje, predviđanje, komunikacija) te četvrta dimenzija: znanstvena i inženjerska praksa prema znanstvenim standardima sljedeće generacije (poddimenzije: pitanja i problemi, analiza i interpretacija, matematičko i računsko razmišljanje, objašnjenja, pronalaženje rješenja i argumentacija).

Ovaj protokol pokazuje koliko je pokazatelja promatrano tijekom STEM nastave i koliko je provedba STEM nastave bila učinkovita. Tijekom evaluacije protokola u obzir nije uzeta frekvencija pokazatelja, nego uočena ponašanja (Milford i Tippet, 2015). Dakle, kako se broj pokazatelja uočenih tijekom STEM nastave povećava, može se zaključiti da STEM nastava koja se provodi u razredu sadrži očekivane sastavnice STEM nastave.

Protokol promatranja nastave preveli su na turski jezik Cetinkaya-Aydin, Sicim Sevim i Yilmaz (2017). Prevedeni Protokol i njegova originalna verzija predani su na pregled stručnjaku koji u Turskoj živi 20 godina, a čiji je materinski jezik engleski. Osim toga, dimenzije i pokazatelje protokola prevedene na turski jezik procijenilo je troje stručnjaka i dalo mišljenje o njihovoj relevantnosti za obrazovanje u ranoj dječjoj dobi. Nakon njihove povratne informacije prikupljeni su potrebni podatci, koje je zatim analiziralo troje stručnjaka te je izračunat Cohenov Kappa koeficijent (Cetinkaya-Aydin, Sicim Sevim i Yilmaz, 2017).

\section{Polustrukturirani intervju za roditelje}

Autori su izradili obrazac za polustrukturirani intervju za roditelje s ciljem dobivanja njihova mišljenja o provedenoj STEM nastavi. Intervju obuhvaća pitanja o definiciji STEM nastave, mišljenjima roditelja o STEM praksi i promjenama koje su roditelji mogli uočiti kod djece nakon provedene STEM nastave.

\section{Polustrukturirani intervju za nastavnike (obrazac $A$ )}

Autori su izradili obrazac A za Polustrukturirani intervju za nastavnike kako bi saznali kakve ideje su nastavnici dobili o STEM nastavi nakon svake provedene STEM aktivnosti. Tako je nastavnik nakon svake aktivnosti odgovorio na pitanja o onome što je dobro odrađeno, kao i o onome što bi trebalo doraditi.

\section{Polustrukturirani intervju za nastavnike (obrazac B)}

Autori su izradili obrazac B za polustrukturirani intervju za nastavnike kako bi saznali mišljenja nastavnika o STEM praksi i promjenama koje su uočili kod djece. Tijekom intervjua nastavnici su odgovarali na pitanja o STEM nastavi općenito, STEM nastavi koja se provodi u predškolskoj dobi te promjenama uočenima kod djece nakon provedene STEM nastave. 


\section{Polustrukturirani intervju za zamjenice ravnatelja}

Autori su izradili obrazac za polustrukturirani intervju za zamjenice ravnatelja kako bi saznali njihova mišljenja o aktualnoj STEM nastavi. Obrazac za intervju uključuje pitanja o definiciji STEM nastave, STEM nastavi koja se provodi u školi te promjenama koje se mogu uočiti kod djece i nastavnika nakon provedenih STEM aktivnosti.

\section{Implementacija}

Istraživanje se provodilo dva puta tjedno tijekom osam tjedana u jesenskom semestru akademske godine 2017./2018. Svaka STEM aktivnost trajala je otprilike 45 minuta, a provodila se u razredu tijekom jutra. Istraživač je je nazočio provedbi aktivnosti na nastavi koristeći se pri tome snimačem zvuka. Nakon toga istraživači su preslušali snimljene materijale i popunili Protokol promatranja nastave. Protokol su popunili različiti istraživači za istu aktivnost, nakon toga su se sastali i usporedili uočene pokazatelje. Tako su postigli potpuni konsenzus.

U ovom istraživanju korištena je metoda intervjua kako bi se dobila mišljenja roditelja, nastavnika i zamjenica ravnatelja. Na kraju osmoga tjedna, nakon što je u potpunosti provedena STEM praksa, roditelji su telefonskim putem obaviješteni o svrsi istraživanja te je naglašeno da je sudjelovanje u njemu dobrovoljno. Dogovoreni su sastanci s roditeljima koji su se dobrovoljno javili. Intervjuirano je ukupno petero roditelja. Svi su intervjui provedeni osobno, licem u lice, u udobnom i tihom okruženju u uredima roditelja, a trajali su otprilike 30 minuta. Tijekom intervjua korišten je snimač zvuka, uz dopuštenje sudionika. Intervjui su provedeni s ciljem prikupljanja informacija o mišljenjima roditelja o STEM nastavi i promjenama koje su uočili kod djece nakon provedbe takve vrste nastave.

Na kraju svake aktivnosti provedeni su intervjui s nastavnicima koji su te STEM aktivnosti provodili, kako bi se dobila njihova mišljenja o takvoj praksi. Intervjui su održani odmah nakon provedenih aktivnosti i trajali su oko 10 minuta. Održani su u ugodnom i tihom okruženju u sobi za sastanke u vrtiću, gdje se nastava i odvijala. Na taj su način i mišljenja nastavnika o provedbi svake STEM aktivnosti uključena u istraživanje. Na kraju osmotjednoga razdoblja, nakon završetka provedbe STEM nastave, održani su intervjui s nastavnikom koji je provodio STEM nastavu i s razrednikom. I ovi su intervjui održani u vrtiću, u sobi za sastanke. Tijekom intervjua korišten je snimač glasa, uz dopuštenje sudionika. Intervjui su provedeni kako bi se dobile ideje nastavnika o STEM nastavi i promjenama koje su uočili kod djece nakon njezine provedbe.

Na kraju, nakon što je STEM nastava provedena u potpunosti, održani su intervju i sa zamjenicama ravnatelja. Intervjui su provedeni u njihovim udobnim i tihim uredima, osobno, licem u lice, uz prethodni dogovor. Trajali su oko 30 minuta, a pomoću njih su dobivena mišljenja zamjenica ravnatelja o STEM nastavi. Osim toga, postavljena su im pitanja o promjenama koje su uočile i kod nastavnika i kod djece, a odgovori su zabilježeni na snimaču zvuka, uz dopuštenje sudionica. 


\section{Analiza podataka}

Podatci prikupljeni tijekom istraživanja analizirani su zasebno. Protokol promatranja nastave popunjen je i evaluiran kao rezultat promatranja nastave. Podatci koji su prikupljeni putem polustrukturiranih intervjua sa zamjenicama ravnatelja, roditeljima i razrednicima opisani su pomoću metode analize sadržaja, koja je jedna od kvalitativnih metoda analize podataka. Analiza sadržaja može se opisati kao način prepoznavanja ključnih pojmova i odnosa koji objašnjavaju prikupljene podatke pomoću detaljne analize (Yıldırım i Şimşek, 1999). Intervjui su prvo transkribirani, a zatim su ih autori evaluirali. U procjenama su obrasci intervjua i pitanja postavljena u njima analizirani zasebno. Nakon evaluacije, autori su zajedno usporedili teme te uz potpuni konsenzus odabrali zajedničke teme. Svaki sudionik u istraživanju dobio je svoju zaporku, ovisno o položaju u instituciji, spolu djece i roditelja i broju roditelja. Na primjer, VP je bila zaporka za zamjenicu ravnatelja, CT za razrednika, IT za nastavnika koji je provodio STEM aktivnosti, a MD1 za prvu majku koja je sudjelovala u istraživanju, a koja je imala kćer. FS1 bila je zaporka za prvog oca koji je sudjelovao u istraživanju, a imao je sina. Brojevi na kraju zaporke podijeljeni su ovisno o tome radi li se o roditelju ženskoga ili muškoga spola. U ovome su istraživanju podatci prikupljeni kako bi se promotrila i ispitala provedba STEM nastave u ranoj dječjoj dobi, kao i mišljenja sudionika (nastavnika, roditelja i rukovodstva škole) o STEM nastavi. U analizi podataka korištene su kvalitativne metode analize podataka.

\section{Rezultati}

\section{Protokol promatranja nastave}

Protokol promatranja nastave koristi se kako bi se utvrdilo postoji li očekivano ponašanje u STEM aktivnostima (Tippet i Milford, 2017). U tom kontekstu, u ovom istraživanju nije se procjenjivala učestalost pokazatelja, nego postojanje takvoga ponašanja u pokazateljima. Dakle, kako se broj pokazatelja uočenih tijekom STEM nastave povećava, može se zaključiti da provedba STEM nastave postaje sve smislenija u procesu učenja. Jedan je od ciljeva Protokola promatranja nastave pomoći nastavnicima $\mathrm{u}$ izradi nastavne pripreme za STEM nastavu kako bi njezinu provedbu učinili smislenom (Milford i Tippet, 2015). Tako pomoću Protokola promatranja nastave nastavnici koji provode STEM nastavu mogu promatrati i STEM nastavu i proces učenja u razredu. $U$ ovome istraživanju uočeno je 39 od ukupno 48 pokazatelja. Osim toga, očekivane karakteristike pronađene su u svakoj dimenziji i poddimenziji Protokola promatranja nastave. Međutim, broj pokazatelja koji su uočeni u poddimenzijama protokola varira. U tablici 1 prikazani su pokazatelji zabilježeni u protokolu. Zbog velikoga broja pokazatelja zaključeno je da je STEM nastava koja se pratila tijekom istraživanja sadržavala očekivane sastavnice STEM nastave. Štoviše, kako ti podatci pokazuju, potrebno je naglasiti da je STEM nastava jako važna u ranom djetinjstvu. Zaključeno je da je prikladna za rano djetinjstvo te da je bila na odgovarajući način 
integrirana u nastavni plan i program ranoga obrazovanja upravo zbog činjenice da su sastavnice Protokola promatranja nastave uočene tijekom cijeloga istraživanja.

Tablica 1.

\section{Intervjui s roditeljima}

Roditeljima su postavljena četiri različita pitanja o STEM nastavi koja se provodila u radu s njihovom djecom.

Kao prvo, od roditelja je zatraženo da opišu STEM nastavu. Troje od petero roditelja odgovorilo je: „Ne znam točno jer nam to nije detaljno objašnjeno”. Jedan roditelj ju je opisao kao „pronalaženje rješenja za stvarne probleme i stvaranje proizvoda koristeći materijale iz svakodnevnoga života kako bi se postigao cilj”. Jedan je roditelj opisao STEM nastavu kao „obrazovni trend integriran u discipline znanosti, inženjerstva i matematike”. Dolje su navedena neka mišljenja roditelja:

„Iskreno, nisam sigurna točno što je njezin sadržaj jer je samo napisano na papiru. To je sve što znamo. Nisu nam dali detaljne informacije." (MD1)

„...to je metoda za postizanje cilja, kako bi se pronašla kreativna rješenja za probleme u svakodnevnom životu. Čini mi se da se pomoću nje stvara proizvod koristeći materijale iz svakodnevnoga života." (MD2)

Kada se roditelje pitalo što misle o STEM nastavi, svi su rekli da „nemaju nikakvo mišljenje jer ih škole nisu obavijestile, a djeca nisu govorila o toj temi”.

„Znam da se provode neke aktivnosti, ali nemam neko određeno mišljenje. Nisu nam rekli što će se raditi. Moj sin mi ne govori o tome." (MS3)

„Ne znam, a moj mi sin ne govori ništa o tome.” (FS2)

Na kraju STEM nastave, roditelje se pitalo jesu li primijetili ikakve promjene kod svoje djece. Četvero roditelja izjavilo je da su primijetili promjenu, ali nisu sigurni je li ona povezana sa STEM nastavom, dok je jedan roditelj rekao da nije primijetio nikakve promjene.

„Nisam siguran jesu li promjene uzrokovane STEM nastavom ili nekom drugom školskom praksom. Možda je njegov nastavnik nešto radio s njima, ali nisam obaviješten o tome koje bih promjene mogao primijetiti kod svojeg djeteta." (FS1)

„Nisam primijetila nikakvu promjenu.” (MD2)

Na kraju, kada se roditelje pitalo o STEM nastavi općenito, svi su bili mišljenja da je neophodno da ih se informira o sadržaju nastave. Štoviše, četvero od petero roditelja zahtijevalo je da budu „upoznati s očekivanim ishodima”, dok je jedan roditelj želio znati „kako takvoj nastavi dati podršku kod kuće”. Ovo su neke od izjava roditelja:

„Mogli su nas obavijestiti o nastavi. Želim znati svrhu te nastave, do kojih promjena ona vodi $i$ što bih trebala napraviti da svojem djetetu dam podršku. Moglo bi biti bolje." (MS3) 
„Da su nas obavijestili o tome što će se raditi na STEM nastavi i kako, možda bismo primijetili promjene kod djece. Ne znam koji su ishodi STEM nastave ili kakvo bi ponašanje moje dijete trebalo imati kao njezin rezultat." (MD1)

\section{Intervju s nastavnikom koji provodi STEM nastavu}

Nastavnici koji provode STEM nastavu intervjuirani su nakon svake aktivnosti. Nakon svake aktivnosti (ukupno 16) tijekom osam tjedana, nastavnik je intervjuiran o STEM praksi koju je primijenio toga dana.

Kao prvo, postavljeno je pitanje: „Koja je aktivnost dobro odrađena?” Odgovori nastavnika prikazani su u Tablici 2.

Tablica 2.

U Tablici 2, nastavnik je naveo da je 11 od 16 aktivnosti bilo orijentirano na cilj, četiri aktivnosti su zadobile i zadržale pažnju učenika, tri aktivnosti su pomogle u ocjenjivanju učenike, dvije su bile povezane s njihovim prijašnjim iskustvima učenja, dok je jedna aktivnost bila usmjerena na zabavu.

„Tijekom toga procesa djeca su uživala i bila usredotočena. Nisu bili primorani..." (IT - 1. implikacija)

„Ovoga tjedna upravljanje razredom je bilo dobro. Dogovorili smo pravila $i$ izgleda da su ih poštivali... Bilo je lijepo odraditi evaluaciju." (IT - 3. implikacija) „Ishod naveden u cilju naglašen je više puta." (IT - 12. implikacija)

Odgovori nastavnika o istoj praksi na pitanje „Koja je praksa loše provedena?” prikazani su u Tablici 3.

Tablica 3.

U Tablici 3 nastavnici su naveli da je 7 od 16 aktivnosti bilo neuspješno zbog slabog upravljanja razredom, pet aktivnosti je propalo zbog nedostatka nastavnih materijala, četiri aktivnosti su bile neuspješne zbog ograničenoga vremena i nedovoljne pripreme nastavnika, dok je jedna aktivnost mogla dovesti do stvaranja krive predodžbe pa zbog toga nije mogla biti dobro provedena.

„Aktivnosti su predstavljale izazov jer se sastoje od znanstvenih procesa koje je teško prikazati - poput činjenice da vjetar nastaje uslijed neujednačenog zagrijavanja. Dala sam sve od sebe kako bih konceptualizirala proces, ali nisam sigurna je li uspjelo. Trebalo bi ga ponoviti više puta." (IT - 7. praksa)

„30 minuta na raspolaganju za provedbu aktivnosti otežalo je cijeli proces. Prije provedbe trebalo je imati nekoga iskustva $i$ više informacija. Međutim, $u$ tome trenutku, nerealno je davati informacije i očekivati proizvod." (IT - 2. praksa)

Na kraju, Tablica 4 pokazuje odgovore nastavnika koji su provodili STEM aktivnosti na pitanje: „Što biste promijenili kada biste ponovno mogli provesti tu aktivnost?” 
Tablica 4.

Kako je prikazano u Tablici 4, kada bi nastavnici ponovno proveli 16 aktivnosti, mijenjali bi materijale u 9 od njih, produžili bi vrijeme i povećali broj materijala, kombinirali aktivnosti i pažljivo koristili pojmove te bi odredili pravila rada u razredu, surađivali s drugim nastavnicima, dodali neke nove pojmove aktivnostima i dali prednost radu u grupama.

„Mogli bismo razgovarati s drugih dvoje kolega prije provedbe prakse. Imala sam nekih pitanja, ali oni nisu znali za to." (IT - 1. praksa)

„Tijekom provedbe, koristila sam „teško” $i$,lagano” umjesto „malo” $i$,veliko”. Trebala sam više pažnje obratiti na svoj izbor riječi. Ova situacija bi mogla u budućnosti dovesti do stvaranja krivih predodžbi.” (IT - 13. praksa)

„Možda bih mogla učenicima dati mogućnost da rade u grupama od 2 ili 3 učenika te svakome dati jednu toplu i jednu hladnu šalicu s vodom.” (IT - 14. praksa)

\section{Intervjui s nastavnicima}

U polustrukturiranim intervjuima (Obrazac B) nastavnicima su postavljena pitanja o definiciji STEM nastave, STEM nastavi koja se provodila i o promjenama koje su primijetili kod djece nakon završetka provedbe STEM nastave.

Kao prvo, nastavnicima je postavljeno pitanje što STEM nastava znači njima samima. Dvoje nastavnika navelo je da STEM nastava uključuje različite discipline. Nadalje, jedan je nastavnik rekao da STEM nastava prikazuje djeci različita stajališta, dok je drugi spomenuo da STEM nastava pruža mogućnost pronalaženja rješenja za probleme te stvara proizvod na temelju toga rješenja.

„Djeca mogu smisliti različite načine razmišljanja zahvaljujući STEM nastavi. Dok izgrađuju brod ili druge stvari, oni ne izrađuju samo slične stvari; zahvaljujući različitim stajalištima, mogu izgraditi originalne stvari.” (CT)

„...možemo opisati STEM nastavu kao nešto što pruža moguće rješenje uz pomoć inženjerskih $i$ tehnoloških vještina $i$ uzima u obzir znanstvene i matematičke teme pri rješavanju stvarnih, svakodnevnih problema ili problema koje postavlja nastavnik.” (IT)

Kada se nastavnike pitalo za mišljenje o STEM nastavi koju su provodili, jedan je nastavnik objasnio da je to sustavna nastava koja uključuje različita iskustva i perspektive te stvara različita stajališta. Drugi je naglasio da STEM nastava djeci omogućava razumijevanje pojmova, učenje tijekom toga procesa i učenje kroz iskustvo.

„Imati druge ljude u razredu tijekom nastave, osim razrednika, $i$ stvoriti nešto zajedno bilo je vrijedno iskustvo... Djeci ste prikazali različita stajališta.” (CT) „Sve su aktivnosti usmjerene na različite ciljeve. Općenito, postoje aktivnosti kojima se podiže razina spremnosti kod djece. Zajedno smo naučili, iskusili $i$ promatrali znanstvene i matematičke pojmove. Sve su aktivnosti bile usmjerene na drugačije ciljeve." (IT) 
Nastavnike se pitalo zašto smatraju da je STEM nastava zanimljiva, a oni su odgovorili da su već prije bili zainteresirani za znanost i matematiku, da su pohađali određene edukacije o toj temi, da je STEM nastava postala popularna i da bi mogla doprinijeti boljoj budućnosti.

„...kada vidite naziv posvuda, kao nastavnik postanete znatiželjni. Također, njezin potencijal da oblikuje budućnost razvija moju znatiželju.”(CT)

„Oduvijek volim znanost. Akademski sam također uključen u nju. Moje matematičke vještine također su dobre, iako su malo zastarjele." (IT)

Nastavnike se također pitalo jesu li uočili bilo kakve promjene kod djece nakon provedene STEM nastave. Dvoje je nastavnika izjavilo da su primijetili neka poboljšanja kod djece u području kreativnosti, izražavanja, sagledavanja problema $s$ različitih stajališta, matematike (slaganje i kategoriziranje) i u razvijanju svijesti o vezi između uzroka i posljedice. Nadalje, nastavnici su izjavili da je STEM nastava kod djece razvijala znatiželju, da su djeca bila opuštenija i da su popravila svoju svijest o određenim materijalima.

„Imala je pozitivan utjecaj na djecu. Postali su znatiželjni o njezinom cilju $i$ rezultatu. Otkrili su bit rada u grupi. Usvajali su pojmove poput kategoriziranja i slaganja." (CT)

„Postojala je velika razlika između prve i posljednje aktivnosti. Uočila sam promjene u njihovoj kreativnosti. Poboljšali su se u usvajanju različitih stajališta... Počeli su se bolje samostalno izražavati. Sagledavali su fenomene s različitih stajališta i pronašli neka rješenja." (IT)

Na kraju, kada ih se pitalo za općenito mišljenje o STEM nastavi, nastavnici su naglasili ulogu nastavnika u STEM nastavi te potrebu za edukacijama. Jedan je nastavnik dijelio njihovu zabrinutost zbog činjenice da bi STEM nastava mogla postati monotona ako se neprestano provodi, a to bi moglo usporiti razvoj obrazovanja.

„Što ako se stalno budemo ponavljali?” (CT)

„Nastavnici su zaista bitni u STEM nastavi jer ona ne znači pružanje izravnih informacija, nego potiče učenike da sami otkrivaju informacije.” (IT)

\section{Intervjui sa zamjenicama ravnatelja}

Zamjenice ravnatelja intervjuirane su uz pomoć pet različitih pitanja o STEM nastavi koja se provodila u razredu.

Kada im je postavljeno pitanje što STEM nastava predstavlja njima, odgovorile su na to pitanje jednom riječju - znatiželju. Jedna je zamjenica ravnatelja definirala STEM nastavu kao „projektnu nastavu koja uključuje inženjerstvo, umjetnost, znanost i matematiku, uz različite perspektive”.

„Mogu je opisati kao projektnu nastavu koja uključuje inženjerstvo, umjetnost, znanost i matematiku, uz različite perspektive." (VP1) 
„Svrha joj je djecu učiniti znatiželjnom, poticati njihovu maštu i pomoći im da uočavaju različite stvari. STEM nije jednostavan akronim; treba zadovoljiti dječju znatižlju i učiniti ih zadovoljnima." (VP2)

Kada su zamjenice ravnatelja pitane za mišljenje o STEM nastavi koju su promatrale, jedna od njih je rekla: „Učinila je našu školu poznatom, a od roditelja smo dobili pozitivnu povratnu informaciju., dok je druga rekla da se takva nastava „temelji na pronalaženju rješenja te da je to sasvim drugačiji tip nastave". Štoviše, rekle su da su izložbu organiziranu na kraju provedbe STEM nastave posjetila djeca iz različitih dobnih skupina pa su se roditelji te djece također zainteresirali za STEM.

„Bila je to dobra prilika i za roditelje i za nas; to će učiniti našu školu poznatom u susjedstvu. Nakon što su djeca predstavila svoje projekte, roditelji su nam dali pozitivne povratne informacije." (VP1)

„To je za nas bilo prekrasno iskustvo, a ujedno i sasvim drugačija praksa. Fokus je na pronalaženju rješenja i mislim da bismo s tom praksom trebali nastaviti."(VP2)

Nakon STEM nastave zamjenice ravnatelja izjavile su da su primijetile pozitivne promjene kod učenika. Djeca su bila uspješna u izražavanju originalnih ideja i nalaženju rješenja za probleme te su mogla postavljati više pitanja. Nadalje, primijetile su također i pozitivne promjene kod nastavnika. Tijekom STEM nastave nastavnici su bili produktivniji, znatiželjniji, pružali su više podrške i preuzimali inicijativu.

„I za najmanju stvar kažemo da se od nje može nešto izraditi. Neki dan su napravili nešto s magnetom. Koristili su svoj proizvod za prikupljanje otpada $i$ za podizanje smeća s poda." (VP1)

„...prije STEM nastave, djeca su bila zainteresirana samo za svoje igračke, no sada planiraju i žele izraditi knjigu." (VP2)

„Da, nastavnik uvijek osmišljava nove projekte. Od roditelja zahtijeva nove materijale. Rade na projektima..." (VP1)

"...kako nastavnik uočava da djeca obraćaju pažnju na nastavu, postavlja im sve više pitanja kako bi potaknuo njihovu znatiželju..."(VP2)

$\mathrm{Na} \mathrm{kraju,} \mathrm{zamjenice} \mathrm{ravnatelja} \mathrm{izrazile} \mathrm{su} \mathrm{svoje} \mathrm{pozitivne} \mathrm{reakcije} \mathrm{na} \mathrm{STEM} \mathrm{nastavu.}$ Voljne su nastaviti istu praksu s učenicima u različitim dobnim skupinama i održati tu praksu tijekom cijele školske godine.

„... Nadam se da će učenici u svim dobnim skupinama imati koristi od takve nastave. Nadam se da ćemo je moći provoditi tijekom godine..."(VP1)

„Želimo da takva nastava postane stalna praksa u našoj školi, kako bismo mogli poticati i održavati znatiželju kod naših učenika..."(VP2)

\section{Rasprava}

Tijekom STEM nastave promatrano je 39 od ukupno 48 pokazatelja, primjenom Protokola promatranja nastave. U istraživanju koje su proveli Tippett i Milford (2017), 
promatrano je 41 od 48 pokazatelja, a to pokazuje da STEM nastava ima 41 sastavnicu učinkovitih STEM praksi. Stoga se STEM nastava može provoditi u ranom djetinjstvu. Slično tome, činjenica da je uočeno 39 od ukupno 48 pokazatelja upućuje na to da je STEM nastava ostvarila očekivane obrazovne ishode, da se STEM nastava može provoditi i s učenicima u ranom djetinjstvu te da STEM nastava može biti na odgovarajući način uključena u nastavu u ranom djetinjstvu. Štoviše, uočeni su svi pokazatelji iz osam poddimenzija: karakteristike i priroda, izrada, promatranje, opisivanje, kategoriziranje, komunikacija, analiza i interpretacija, objašnjavanje i pronalaženje rješenja. Dakle, ishodi ovih poddimenzija i zahtjevi STEM nastave naglašeni su u ovome istraživanju. Uočena su i 2 od 3 pokazatelja iz 7 poddimenzija, a to su: obrasci i interakcije, pretvaranje, društveno-dramska, istraživanje okoline, predviđanje, pitanja i problemi, matematičko i računsko razmišljanje. Ovaj rezultat pokazuje da su ishodi poddimenzija i zahtjevi STEM nastave bili spomenuti tijekom procesa, dok se obrazovni program kojemu su ove poddimenzije cilj treba još doraditi. Na kraju, uočen je samo jedan pokazatelj poddimenzije ,argument”. Zato je potrebno revidirati i obogatiti obrazovni program te poddimenzije. Čini se da je Protokol promatranja nastave svojevrstan vodič za nastavnike koji provode STEM nastavu. Tijekom pripremanja obrazovnih programa i nastavnih priprema za STEM nastavu za učenike rane dobi, moglo bi biti učinkovito koristiti ovaj protokol kao smjernicu. Na taj bi se način uključivanje STEM-a u obrazovni program moglo unaprijediti, a nastavnici bi bolje mogli promatrati proces učenja. Nadalje, rezultati ovoga istraživanja mogli bi biti i vodič za nastavnike pri izradi obrazovnih programa i nastavnih priprema koji obuhvaćaju sve faktore STEM nastave. Na temelju ovih rezultata, STEM nastava, koja naglašava važnost obrazovanja za učenike u ranoj dječjoj dobi, trebala bi biti uključena $u$ obrazovne politike usmjerene na učenike $u$ ranoj dobi te bi se trebala provoditi.

Kako je pokazalo ovo istraživanja, roditelji nisu bili dovoljno informirani o STEM nastavi. To je moglo utjecati na njihove ideje i mišljenja o STEM nastavi. Roditelji su izjavili da nisu znali što STEM nastava znači te da nisu mogli uočiti nikakvu vezu između STEM nastave i promjena koje su uočili kod svoje djece - znatiželje, postavljanja mnogobrojnih pitanja, usredotočenosti na rješenja i povećanog interesa za matematiku kao nastavni predmet. Akgunduz i Akpinar (2018) u svojem su istraživanju naglasili da nisu mogli primijetiti nikakve pozitivne promjene u vještinama 21. stoljeća, znatiželji i motivaciji djece. Kako je navedeno u postojećoj literaturi, prema onome što navode Tippett i Milford (2017), roditelji su zahtijevali informacije o STEM nastavi. Taj rezultat naveli su Gulgun, Yılmaz i Caglar (2017) te tako pokazali da, ako su roditelji informirani o STEM nastavi, to može imati pozitivan utjecaj na obrazovni proces, što ide u prilog ovome istraživanju. To znači da nedostatak informacija može roditelje spriječiti da saznaju sve što je bitno o STEM nastavi. Buduća istraživanja mogla bi se fokusirati na uključivanje roditelja u obrazovni proces kroz organizaciju informativnih seminara za njih.

Nastavnici koji su provodili STEM nastavu naveli su da je činjenica da je praksa bila orijentirana na cilj i dobra za upravljanje razredom i tako omogućila evaluaciju i 
usmjerila pažnju učenika pokazala da je praksa dobro provedena. Postojeća literatura također ide u prilog saznanjima da su aktivnosti STEM nastave orijentirane na cilj (Akgunduz i Akpinar, 2018). Dijelovi koji nisu dobro provedeni bili su uglavnom problemi u upravljanju razredom, nedostatak materijala, ograničeno vrijeme, nedovoljna pripremljenost nastavnika i mogućnost stvaranja krivih predodžbi. Ograničeno vrijeme za aktivnosti također se spominje u postojećoj literaturi (Ugras, 2017). Nadalje, nastavnica je naglasila da bi voljela obogatiti materijale, povećati vrijeme potrebno za praksu, povećati broj materijala, naglasiti vezu između svake prakse, koristiti pojmove pažljivije, odrediti razredna pravila, surađivati s ostalim nastavnicima, dodati nove pojmove i primjenjivati više rada u grupama, ako bude ponovno primjenjivala istu praksu. Nastavnica može uočiti koji dijelovi nisu dobro funkcionirali tijekom prakse i smatra da bi u budućnosti isti taj proces mogla unaprijediti, što pokazuje da je otvorena za razvoj i poboljšanje vlastitoga rada i dobra u uočavanju nedostataka. Izrada tablice pomoću koje bi se nastavnici koji provode STEM nastavu mogli samovrednovati na kraju obrazovnoga procesa mogla bi biti jako korisna za prepoznavanje poteškoća. Slično tome, nastavnici bi mogli koristiti i Protokol promatranja nastave (Tippet i Milford, 2017) i tako promatrati koliko STEM faktora njihova obrazovna aktivnost sadrži. Na taj bi način mogli zadovoljiti potrebne kriterije STEM nastave.

Tijekom intervjua, nastavnici su izjavili da STEM nastava uključuje različite discipline, što je u skladu s onime što se navodi i u postojećoj literaturi (Akgunduz i sur., 2015; Aydagul i Terzioglu, 2014; Balat i Gunsen, 2017; Breiner i sur., 2012). Nadalje, prema tim nastavnicima, STEM nastava pokazuje djeci da postoje različita stajališta i iskustva te potiče učenje o pojmovima kroz iskustvo, vještine rješavanja problema i stvaranja nečega na temelju rješenja. Ta su saznanja u skladu s istraživanjima koja su proveli Akgunduz i Akpinar (2018), Basaran (2018) i Yıldırım i Turk (2018). Nastavnici su pripisali svoj interes za STEM nastavu svojem prijašnjem interesu za znanost i matematiku, seminarima koje su pohađali, popularnosti STEM nastave i potencijalu da se doprinese razvoju obrazovanja u budućnosti. Buduća bi se istraživanja mogla fokusirati na stavove nastavnika i svijest o STEM nastavi.

Nastavnici su kod djece uočili neke promjene koje su rezultat STEM nastave. Djeca su razvila veću kreativnost, vještine samoizražavanja, različite perspektive, matematičke vještine (nizanje, kategoriziranje) te svijest o razlozima i posljedicama. Nadalje, naveli su da su djeca postala znatiželjnija i usklađena te da su razvila svijest o korištenju različitih materijala. Ti su rezultati u skladu s rezultatima domaće i strane literature (Akgunduz i Akpinar, 2018; Basaran, 2018; Tippett i Milford, 2017; Ugras, 2017; Ylldırım i Turk, 2018).

Nastavnici smatraju da su edukacije i seminari o STEM nastavi za nastavnike neophodni jer bi onda mogli i sami provoditi STEM nastavu, pripremati kvalitetne materijale i pružati podršku učenicima tijekom cijeloga procesa. Tome ide u prilog $\mathrm{i}$ istraživanje koje je proveo Ozbilen (2018). Nadalje, Akgunduz i Akpinar (2018) u svojem su istraživanju naglasili važnost prepoznavanja kvalitetnih i preciznih materijala 
i njihovoga korištenja s ciljem razvoja djece. To znači da je prepoznavanje i primjena kvalitetnih materijala od ključne važnosti za razvoj djece. Također su izrazili bojazan da STEM nastava može postati monotona ako se provodi cijelo vrijeme. Kako bi se taj problem spriječio, nastavnici mogu pohađati edukacije kada već rade u obrazovnom sustavu, mogu pohađati seminare i dijeliti svoje znanje i iskustvo o STEM praksi na raznim platformama, što je u skladu s postojećom literaturom o toj temi (Gulgun, Yulmaz i Caglar, 2017).

Intervjui sa zamjenicama ravnatelja novina su u STEM literaturi. Tippett i Milford (2017) navode da bi moglo biti korisno provesti intervjue s ravnateljima škola. U intervjuima sa zamjenicama ravnatelja STEM nastava opisana je kao projektna nastava koja uključuje inženjerstvo, umjetnost, znanost i matematiku, s mnogobrojnim perspektivama, a zamjenice su rekle da takva nastava kod djece potiče znatiželju. Također su dobile pozitivne povratne informacije od roditelja i učenika, što je u skladu $s$ istraživanjem koje je proveo Basaran (2018). Ti rezultati upućuju na činjenicu da ravnatelji škola pridaju veliku važnost tome da njihove škole postanu prepoznatliive po različitim aktivnostima. Zamjenice ravnatelja također su uočile pozitivne promjene kod djece i nastavnika. Na primjer, učenici su postali uspješniji u osmišljavanju originalnih ideja, pronalaženju učinkovitih rješenja ili su postali znatiželjniji i počeli postavljati više pitanja. Nastavnici su postali produktivniji, zainteresiraniji, pružali su više podrške i preuzimali inicijativu. Pozitivna povratna informacija pokazuje da su zamjenice ravnatelja zadovoljne STEM nastavom i da su je voljne provoditi s djecom različite dobi. I one bi također mogle pohađati neke edukacije i seminare i tako bi STEM nastava prevladala među nastavnicima.

\section{Zaključak}

U ovome istraživanju promatrano je 39 od 48 pokazatelja koji moraju biti uključeni u STEM nastavu u ranoj dječjoj dobi. Zato se može reći da STEM nastava koja se provodila u sklopu ovoga istraživanja ima moguće karakteristike STEM nastave u ranoj dječjoj dobi i da se STEM nastava koja se provodila može na odgovarajući način integrirati u nastavu za djecu u ranoj dobi. Tippett i Milford (2017) u svojem su istraživanju naveli koji pokazatelji moraju biti uključeni u STEM nastavu u ranoj dječjoj dobi, koristeći Protokol promatranja nastave. Kako se broj promatranih pokazatelja u protokolu povećava, ističe se da STEM nastava koja se provodi ima karakteristike STEM nastave za ranu dječju dob. U istraživanju koje su proveli Tippett i Milford (2017) uočen je 41 od ukupno 48 pokazatelja, a taj rezultat pokazuje da STEM nastava ima 41 sastavnicu učinkovitih STEM praksi. Stoga se STEM nastava može provoditi u ranom djetinjstvu što je u tom kontekstu slično rezultatima ovoga istraživanja.

Uz to, u intervjuima s nastavnicima i ravnateljima škola naglašeno je da STEM nastava koja se provodila ima pozitivan utjecaj na razvoj djece tako što djeci pruža različite perspektive. Međutim, intervjui s roditeljima predstavljaju ograničenje ovoga istraživanja. Od 15 roditelja, samo je 5 roditelja iz eksperimentalne skupine sudjelovalo 
u istraživanju, a naveli su da nisu imali informacije o STEM nastavi općenito, kao ni o STEM nastavi koja se u školi provodila. Stoga se nije moglo dobiti dovoljno podataka $\mathrm{u}$ dijelu istraživanja koji se provodio s obiteljima. U budućim istraživanjima, kroz veću suradnju s obiteljima, trebalo bi se dobiti više informacija od obitelji, vezano uz STEM nastavu u ranoj dječjoj dobi. 